\title{
ANALISIS PENGARUH KEPEMIMPINAN, KOMPENSASI, PELATIHAN DAN \\ PENGEMBANGAN TERHADAP KEPUASAN KERJA DAN PRODUKTIVITAS KERJA PEGAWAI BADAN PERTANAHAN NASIONAL SE- PROVINSI NUSA TENGGARA BARAT
}

\author{
Chici Irianti ${ }^{1}$ ) \\ Agusdin 2) \\ Hermanto ${ }^{2}$ )
}

\begin{abstract}
This research is aimed at analyzing the effect of leadership on work satisfaction, the effect of compensation on work satisfaction, the effect of training and development on work satisfaction, the effect of leadership of productivity, the effect of compensation on productivity, the effect of training and development on productivity, and the effect of work satisfaction on productivity of the of employees of national land agency of West Nusatenggara.

This research is quantitative-associative causal study. The respondents are the civil servant of land agency of West Nusatenggara who had been working for at least 5 years and have the position of the head off sub-division (echelon IV) in provincial and district office in West Nusatenggara. They are 79 respondents from who the data collected through questionnaires. The data were analyzed with Partial Least Square (PLS) using software of SmartPLS version 3.

The research showed that leadership has positive but not significant effect on work satisfaction, compensation has positive and significant effect on work satisfaction, training and development has positive and significant effect on work satisfaction, leadership has positive but not significant effect on productivity, compensation has negative and not significant effect on productivity, training and development has positive but not significant effect on productivity, work satisfaction has positive and significant effect on productivity of employees of national land agency of West Nusatenggara. Compensation has dominant effect on work satisfaction, and work satisfaction also has dominant effect of the productivity of employees of national land agency of West Nusatenggara.
\end{abstract}

Keywords: leadership, work satisfaction, compensation, training and development, and productivity.

\section{Pendahuluan}

Aset yang paling penting yang harus dimiliki oleh organisasi dan harus diperhatikan dalam manajemen adalah tenaga kerja atau manusia (sumber daya manusia). Sumber daya manusia adalah orang-orang yang merancang dan menghasilkan barang atau jasa, mengawasi mutu, memasarkan produk, mengalokasikan sumber daya finansial serta merumuskan seluruh strategi dan tujuan organisasi (Samsudin, 2010). Sumber daya manusia merupakan satu-satunya sumber daya yang memiliki akal perasaan, keinginan keterampilan, pengetahuan, dorongan, daya dan karya. Semua potensi SDM tersebut berpengaruh terhadap upaya organisasi dalam mencapai tujuan. Betapapun majunya teknologi, perkembangan informasi, tersedianya modal dan memadainya bahan, jika tanpa SDM sulit organisasi itu mencapai tujuannya (Sutrisno, 2015).

Produktivitas kerja merupakan masalah yang selalu menjadi perhatian berbagai organisasi dan perusahaan, dimana produktivitas mempunyai peranan yang sangat

\footnotetext{
${ }^{1}$ Mahasiswa MM UNRAM

${ }^{2}$ Dosen Program MM UNRAM dan Jurusan Manajemen FE UNRAM
} 


\section{TMM JURNAL MAGISTER MANAJEMEN UNIVERSITAS MATARAM UNRAM

\author{
Maret 2017
}

penting dalam pencapaian tujuan organisasi atau perusahaan. Tenaga kerja yang produktif adalah tenaga kerja yang cekatan, kreatif, dan inovatif yang dapat menghasilkan barang dan jasa sesuai mutu dengan waktu yang singkat (efektif dan efisien). Menurut Ravianto (1998 dalam Yuniarsih, et al., 2008) menyebutkan bahwa faktor-faktor yang mempengaruhi produktivitas kerja pegawai meliputi: pendidikan, keterampilan, disiplin, sikap dan etika kerja, motivasi, gaji, kesehatan, teknologi,manajemen dan kesempatan berprestasi.

Kepuasan kerja merupakan hal yang bersifat individu dan memiliki tingkat kepuasan yang berbeda-beda. Salah satu definisi kepuasan kerja menurut Joseph Tiffin (2000 dalam Moh. As'ad, 2004), menjelaskan bahwa kepuasan kerja adalah sikap karyawan terhadap pekerjaan, situasi kerja, kerjasama diantara pimpinan dan sesama karyawan dan faktor-faktor yang mempengaruhi kepuasan kerja antara lain faktor kepuasan finansial, kepuasan fisik, kepuasan sosial dan kepuasan psikologi. Dampak kepuasan kerja cenderung terpusat pada kinerja karyawan, tingkat kehadiran dan tingkat keluar masuknya karyawan (turnover). Hanya pegawai yang puas dengan pekerjaannya yang bisa mencapai tingkat komitmen, produktivitas, dan prestasi kerja yang tinggi.

Pencapaian Kinerja Program Kementerian Agraria dan Tata Ruang/ BPN RI Tahun 2015 secara keseluruhan hanya mencapai 70 \% dalam kategori Cukup. Begitupula bila dibandingkan dengan Laporan Akuntabilitas Kinerja Kementerian/ Lembaga Tahun 2015 oleh KemenPAN\&RB menunjukan Kementerian ATR/ BPN RI hanya berada di urutan ke52 dengan nilai 62,11 dalam predikat Baik dari 77 Kementerian/ Lembaga. Kinerja Program Prioritas Sertipikasi Prona Tahun 2015 pada Aplikasi SKMPP menunjukan BPN NTB hanya menduduki peringkat ke-24 dari 33 provinsi di Indonesia. Hal diatas menunjukan produktivitas kerja dan kinerja Kementerian ATR/ BPN RI dan BPN NTB yang masih dalam kategori Cukup.

Berdasarkan hasil observasi dan wawancara pendahuluan terhadap fenomena di BPN NTB, didapatkan perilaku sebagian PNS di tingkat kantor wilayah maupun kantor pertanahan kabupaten/ kota menunjukan perilaku-perilaku seperti lambatnya pegawai dalam bekerja, rendahnya prestasi, rendahnya kinerja dan masalah disiplin pegawai yang mencerminkan tingkat kepuasan kerja yang rendah (David, 2011). Berdasarkan hasil wawancara dengan tujuh pegawai didapatkan bahwa empat dari tujuh pegawai $(57 \%)$ kurang puas terhadap aspek pengawasan dan pengarahan yang dilakukan oleh pimpinan terhadap pegawai, perhatian pimpinan terhadap pegawai, kurangnya diklat/ pelatihan yang diberikan, pembagian jasa pelayanan yang belum baik dan belum adanya reward atas hasil kerja yang dicapai oleh pegawai. Kondisi di atas mengindikasikan adanya permasalahan terkait kepuasan kerja pegawai yang berdampak pada produktivitas kerja di BPN NTB.

Dari fenomena dan data di BPN NTB serta didukung pendapat para ahli dan hasil penelitian terdahulu, saya tertarik untuk meneliti "Analisis Pengaruh Kepemimpinan, Kompensasi, Pelatihan dan Pengembangan terhadap Kepuasan Kerja dan Produktivitas Kerja Pegawai BPN se- Provinsi NTB".

\section{Perumusan Masalah}

1. Apakah ada pengaruh Kepemimpinan terhadap Kepuasan Kerja Pegawai BPN NTB?

2. Apakah ada pengaruh Kompensasi terhadap Kepuasan Kerja Pegawai BPN NTB?

3. Apakah ada pengaruh Pelatihan dan Pengembangan terhadap Kepuasan Kerja Pegawai BPN NTB? 


\section{Maret 2017}

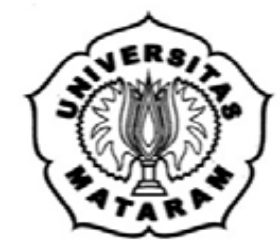

4. Apakah ada pengaruh Kepemimpinan terhadap Produktivitas Kerja Pegawai BPN NTB?

5. Apakah ada pengaruh Kompensasi terhadap Produktivitas Kerja Pegawai BPN NTB?

6. Apakah ada pengaruh Pelatihan dan Pengembangan terhadap Produktivitas Kerja Pegawai BPN NTB?

7. Apakah ada pengaruh Kepuasan Kerja terhadap Produktivitas Kerja Pegawai BPN NTB?

\section{Landasan Teori}

\subsection{Kepemimpinan}

\section{Pengertian Kepemimpinan}

Robbins (2008) menyatakan kepemimpinan "sebagai kemampuan untuk mempengaruhi suatu kelompok guna mencapai sebuah visi atau serangkaian tujuan yang ditetapkan". Sedangkan menurut Anoraga (dalam Sutrisno, 2012) kepemimpinan adalah "kemampuan untuk mempengaruhi pihak lain, melalui komunikasi baik langsung maupun tidak langsung dengan maksud untuk menggerakkan orang-orang agar dengan pengertian, kesadaran, dan senang hati bersedia mengikuti kehendak pimpinan itu".

\section{Fungsi Kepemimpinan}

Fungsi - fungsi kepemimpinan bagi seorang manajer adalah:

1. Fungsi perencanaan

Seorang pemimpin perlu membuat perencanaan yang menyeluruh bagi organisasi dan bagi diri sendiri selaku penanggung jawab tercapainya tujuan organisasi.

2. Fungsi memandang ke depan

Seorang pemimpin yang senantiasa memandang ke depan berarti akan mampu mendorong apa yang akan terjadi serta selalu waspada terhadap kemungkinan. Hal ini memberikan jaminan bahwa jalannya proses pekerjaan ke arah yang dituju akan dapat berlangusng terus menerus tanpa mengalami hambatan dan penyimpangan yang merugikan. Oleh sebab seorang pemimpin harus peka terhadap perkembangan situasi baik di dalam maupun diluar organisasi sehingga mampu mendeteksi hambatan-hambatan yang muncul, baik yang kecil maupun yang besar.

3. Fungsi pengembangan loyalitas

Pengembangan kesetiaan ini tidak saja diantara pengikut, tetapi juga unutk para pemimpin tingkat rendah dan menengah dalam organisai. Untuk mencapai kesetiaan ini, seseorang pemimpin sendiri harus memberi teladan baik dalam pemikiran, kata-kata, maupun tingkah laku sehari-hari yang menunjukkan kepada anak buahnya pemimpin sendiri tidak pernah mengingkari dan menyeleweng dari loyalitas segala sesuatu tidak akan dapat berjalan sebagaimana mestinya.

4. Fungsi pengawasan

Fungsi pengawasan merupakan fungsi pemimpin untuk senantiasa meneliti kemampuan pelaksanaan rencana. Dengan adanya pengawasan maka hambatanhambatan dapat segera diketemukan, untuk dipecahkan sehingga semua kegiatan kembali berlangsung menurut rel yang telah ditetapkan dalam rencana .

5. Fungsi mengambil keputusan

Pengambilan keputusan merupakan fungsi kepemimpinan yang tidak mudah dilakukan. Metode pengambilan keputusan dapat dilakukan secara individu, 


\section{Maret 2017}

kelompok tim atau panitia, dewan, komisi, referendum, mengajukan usul tertulis dan lain sebagainya.

6. Fungsi memberi motivasi

Seorang pemipin perlu selalu bersikap penuh perhatian terhadap anak buahnya. Pemimpin harus dapat memberi semangat dan mempengaruhi anak buahnya agar rajin bekerja dan menunjukkan prestasi yang baik terhadap organisasi yang dipimpinnya. Pemberian hadiah, pujian atau ucapan terima kasih sangat diperlukan oleh anak buah sebab mereka merasa bahwa hasil jerih payahnya diperhatikan dan dihargai oleh pemimpinnya.

Dimensi Kepemimpinan

Menurut Kouzes dan Posner, (2004) Dimensi Kepemimpinan yakni :

1. Jujur. Kejujuran berkaitan erat dengan nilai-nilai dan etika.

2. Berorientasi ke depan

Kemampuan menentukan visi, misi, dan memilih tujuan yang diinginkan, ke arah mana perusahaan, atau komunitas akan dibawa.

3. Kompeten

Kompetensi kepemimpinan mengacu pada catatan prestasi si pemimpin dan kemampuannya untuk menyelesaikan pekerjaan. Seorang pemimpin harus mampu memberi contoh, inspirasi, tantangan, memungkinkan orang bertindak, dan memberi semangat pada bawahannya.

4. Membangkitkan semangat (motivasi)

Kepemimpinan yang membangkitkan semangat dapat memenuhi kebutuhan para bawahannya akan arti dan tujuan dalam hidup, artinya menjadikan anggotaya lebih bersemangat, positif, dan optimis mengenai masa depan yang memberikan harapan pada orang lain.

\subsection{Kompensasi}

\section{Pengertian Kompensasi}

Menurut Dessler, (2015) kompensasi karyawan adalah semua bentuk bayaran atau imbalan yang diberikan kepada karyawan dan timbul dari hubungan kerja mereka. Menurut Rivai dan Sagala, (2011) kompensasi merupakan sesuatu yang diterima karyawan sebagai pengganti kontribusi jasa mereka pada perusahaan.

Kompensasi adalah total seluruh imbalan yang diterima para karyawan sebagai ganti jasa yang telah mereka berikan (Mondy, 2008). Martoyo, (2007) mendefinisikan kompensasi adalah pengaturan keseluruhan pemberian balas jasa bagi "employers" maupun "employees" baik yang langsung berupa uang (finansial) maupun yang tidak langsung berupa uang (non-finansial). Dari definisi-definisi diatas dapat disimpulkan bahwa kompensasi merupakan semua bentuk bayaran atau imbalan yang diterima oleh karyawan atas kontribusi jasa yang diberikan kepada organisasi. Berupa kompensasi finansial (langsung dan tidak langsung) serta kompensasi non-finansial.

\section{Komponen-Komponen Kompensasi}

Menurut Mathis dan Jackson, (2006) ada dua jenis umum kompenen nyata dari sebuah program kompensasi yaitu kompensasi langsung dan kompensasi tidak langsung :

1) Kopensasi langsung berupa gaji pokok dan penghasilan tidak tetap. Gaji pokok adalah kompensasi dasar yang diterima seorang karyawan, biasanya berupa upah atau gaji. Upah adalah imbalan kerja yang dihitung secara langsung berdasarkan pada 
jumlah waktu kerja. Gaji adalah imbalan kerja yang tetap untuk setiap periode tanpa menghiraukan jumlah jam kerja. Sedangkan penghasilan tidak tetap (variabel pay) merupakan jenis kompensasi yang dihubungkan dengan kinerja individual, tim, atau organisasional.Penghasilan tidak tetap yakni bonus, insentif, opsi saham.

2) Kompensasi tidak langsung biasanya terdiri atas tunjangan.Tunjangan merupakan sebuah penghargaan tidak langsung yang diberikan kepada karyawan atau sekelompok karyawan sebagai bagian dari keanggotaan organisasional.Tunjangan dapat berupa asuransi kesehatan/jiwa, cuti berbayar, dana pensiun, kompensasi pekerja dan lain-lain.

Asas-Asas, Tujuan dan Sistem Kompensasi

Menurut Suatno dan Priansa, (2011) asas-asas pemberian kompensasi yaitu:

a. Asas Keadilan

Kompensasi mempengaruhi perilaku karyawan dalam organisasi sehingga pemberian kompensasi yang tidak berdasarkan asas keadilan akan mempengaruhi kondisi kerja karyawan. Asas keadilan ialah adanya konsistensi imbalan bagi para karyawan yang melakukan tugas dengan bobot yang sama. Kompensasi yang baik harus seminimal mungkin mengurangi keluhan atau ketidakpuasan yang timbul dari karyawan.

b. Asas Kelayakan dan Kewajaran

Kompensasi yang diterima karyawan harus dapat memenuhi kebutuhan dirinya beserta keluarganya, pada tingkatan yang layak dan wajar. Sehingga besaran kompensasi yang akan diberikanakan mencerminkan status, penakuan, dan tingkat pemenuhan kebutuhan yang akan dinikmati oleh karyawan beserta keluarganya. Tolak ukur layak berpijak pada standar upah minimum regional (UMR), baik ditingkat provinsi, maupun tingkat kota/ kabupaten. Sedangkan kompensasi yang wajar berarti besaran kompensasi harus mempertimbangkan faktor-faktor seperti prestasi kerja, pendidikan, jenis pekerjaan, risiko pekerjaan, tanggung jawab, jabatan dan lain-lain.

Menurut Suwatno dan Priansa, (2011) tujuan-tujuan kompensasi :

a. Ikatan kerjasama

Pemberian kompensasi akan menciptakan suatu ikatan kerja sama yang formal antara pengusaha (perusahaan) dengan karyawan dalam kerangka organisasi, dimana pengusaha dan karyawan saling membutuhkan.

b. Kepuasan Kerja

Dengan mengerahkan kemampuan, pengetuhuan, keterampilan, waktu serta tenaga, yang semuanya ditujukan bagi pencapaian tujuan organisasi. Oleh karena itu, pengusaha harus memberikan kompensasi yang sesuai dengan apa yang telah diberikan oleh karyawan tersebut sehingga akan memberikan kepuasan kerja bagi karyawan.

c. Pengadaan Efektif

Pengadaan karyawan akan efektif jika dibarengi dengan program kompensasi yang menarik. Dengan program pemberian kompensasi yang menarik, maka calon karyawan yang berkualifikasi baik dengan kemampuan dan keterampilan tinggi akan muncul, sesuai dengan kriteria yang ditetapkan oleh perusahaan.

d. Motivasi

Kompensasi yang layak memotivasi karyawan untuk memberikan kinerja terbaik dan menghasilkan produktivitas kerja yang optimal. Untuk meningkatkan motivasi 


\section{Maret 2017}

bagi karyawan, perusahaan biasanya memberikan insentif berupa uang dan hadiah lainnya.

e. Menjamin Keadilan

Kompensasi yang baik akan menjamin terjadinya keadilan diantara karyawan dalam organisasi. Pemberian kompensasi juga berkaitan dengan keadilan internal maupun keadilan eksternal. Keadilan internal berkaitan dengan pembayaran kompensasi dihubungkan dengan nilai relatif dari suatu jabatan, tugas, dan prestasi kerja karyawan. Sementara keadilan eksternal berkaitan dengan pembayaran bagi karyawan pada suatu tingkat yang dengan pembayaran yang diterima oleh karyawan lainnya yang bekerja di perusahaan lain.

f. Disiplin

Pemberian kompensasi yang memadai akan mendorong tingkat kedisiplinan karyawan dalam bekerja. Karyawan akan menyadari serta menaati peraturanperaturan yang berlaku dalam perusahaan. Perilaku disiplin karyawan ditampilkan sebagai bentuk wujud terimakasih karyawan terhadap perusahaan atas kompensasi yang telah mereka terima.

g. Pengaruh Serikat Pekerja

Serikat ini akan mempengaruhi besar kecilnya kompensasi yang diberikan perusahaan bagi karyawannya. Apabila serikat buruhnya kuat, maka bisa dipastikan tingkat kompensasi yang diberikan perusahaan bagi karyawan tinggi, begitupun sebaliknya.

h. Pengaruh Pemerintah

Pemerintah menjamin atas pekerjaan dan penghidupan yang layak melalui kebijakan perundangan dan regulasi, pemerintah mengeluarkan berbagai macam peraturan yang pada intinya untuk melindungi pekerja, sekaligus mendorong investasi dari para pengusaha agar mau menanamkan modalnya. Berkaitan dengan kompensasi, pemerintah menetapkan besarnya batas upah minimal (UMR) atau balas jasa yang layak diberikan pengusaha (perusahaan) untuk karyawannya, agar pengusaha tidak bertindak sewenang-wenang dalam menetapkan besarnya balas jasa.

\subsection{Pelatihan dan Pengembangan}

\section{Pengertian Pelatihan dan Pengembangan}

Pelatihan (training) merupakan proses pembelajaran yang melibatkan perolehan keahlian, konsep, peraturan, atau sikap untuk meningkatkan kinerja karyawan (Simamora, 2006). Menurut Pasal 1 Ayat 9 Undang-Undang Nomor 13 Tahun 2003 Tentang Ketenagakerjaan, (dalam Simamora, 2006) pelatihan kerja adalah keseluruhan kegiatan untuk memberi, memperoleh, meningkatkan serta mengembangkan kompetensi kerja, produktivitas, disiplin, sikap dan etos kerja pada tingkat keterampilan dan keahlian tertentu sesuai jenjang dan kualifikasi jabatan dan pekerjaan.

Pengembangan (development) diartikan sebagai penyiapan individu untuk memikul tanggung jawab yang berbeda atau yang Iebih tinggi dalam perusahaan, organisasi, lembaga atau instansi pendidikan. Menurut (Handoko, 2001) pengertian latihan dan pengembangan adalah berbeda. Latihan (training) dimaksudkan untuk memperbaiki penguasaan berbagal ketrampilan dan teknik pelaksanaan kerja tertentu, terinci dan rutin. Yaitu latihan rnenyiapkan para karyawan (tenaga kerja) untuk 
melakukan pekerjaan-pekerjaan sekarang. Sedangkan pengembangan (Developrnent) mempunyai ruang lingkup Iebih luas dalam upaya untuk memperbaiki dan meningkatkan pengetahuan, kemampuan, sikap dan sifat-sifat kepribadian.

Pengembangan cenderung lebih bersifat formal, menyangkut antisipasi kemampuan dan keahlian individu yang harus dipersiapkan bagi kepentingan jabatan yang akan datang. Sasaran dan program pengembangan menyangkut aspek yang lebih luas yaitu peningkatan kemampuan individu untuk mengantisipai perubahan yang mungkin terrjadi tanpa direncanakan (unplened change) atau perubahan yang direncanakan (planed change). (Syafaruddin, 2001).

Tujuan dan Manfaat Pelatihan dan Pengembangan

Menurut Andrew F. Sikula, (1981) tujuan pelatihan dan pengembangan adalah :

\section{a. Productivity}

Meningkatkan kemampuan, pengetahuan, keterampilan dan perubahan tingkah laku. Hal ini dapat diharapkan dapat meningkatkan produktivitas.

b. Quality

Memperbaiki kualitas dari tenaga kerja dan diharapkan akan dapat memperkecil kemungkinan terjadinya kesalahan dalam bekerja. Dengan demikian kualitas dari output yang dihasilkan akan tetap terjaga bahkan meningkat.

c. Human Resource Planing

Perencanaan SDM yakni memudahkan organisasi menempatkan pekerja untuk mengisi kekosongan jabatan dalam suatu perusahaan dengan terlebih dahulu diberikan pelatihan agar memperoleh tenaga kerja dengan kualitas yang sesuai.

d. Morale

Diharapkan dengan adanya pelatihan akan dapat meningkatkan prestasi kerja dari karyawan sehingga akan dapat menimbulkan peningkatan upah karyawan. Hal tersebut akan dapat meningkatkna moril kerja karyawan untuk lebih bertanggung jawab terhadap tugasnya.

e. Indirect Compensation

Pemberian balas jasa atas prestasi yang telah dicapai pada waktu yang lalu, sehingga mengikuti program tersebut tenaga kerja yang bersangkutan mempunyai kesempatan untuk lebih mengembangkan diri.

f. Health and Safety

Mencegah atau mengurangi terjadinya kecelakaan kerja dalam suatu perusahaan sehingga akan menciptakan suasana kerja yang tenang, aman dan adanya stabilitas pada sikap mental mereka.

g. Obsolence prevention

Mendorong inisiatif dan kreativitas tenaga kerja, sehingga tenaga kerja terhindar dari sifat kadaluwarsa. Artinya kemampuan yang dimiliki oleh tenaga kerja dapat menyesuaikan diri dengan perkembangan teknologi.

h. Personal Growth

Memberikan kesempatan untuk meningkatkan pengetahuan dan kemampuan yang dimiliki termasuk meningkatkan perkembangan pribadinya.

\section{Manfaat Pelatihan dan Pengembangan}

Pelatihan mempunyai andil besar dalam menentukan efektifitas dan efisiensi organisasi. Beberapa manfaat nyata yang ditangguk dari program pelatihan dan pengembangan (Simamora, 2006) adalah:

a. Meningkatkan kuantitas dan kualitas produktivitas. 


\section{Maret 2017}

b. Mengurangi waktu belajar yang diperlukan karyawan untuk mencapai standar kinerja yang dapat diterima.

c. Membentuk sikap, loyalitas, dan kerjasama yang lebih menguntungkan.

d. Memenuhi kebutuhan perencanaan semberdaya manusia

e. Mengurangi frekuensi dan biaya kecelakaan kerja.

f. Membantu karyawan dalam peningkatan dan pengembangan pribadi.

Faktor-Faktor yang berperan dalam Pelatihan dan Pengembangan

Menurut Rivai dan Sagala, (2011), dalam pelaksanaan pelatihan, ada beberapa faktor yang berperan yaitu instruktur, peserta, materi (bahan), metode, tujuan pelatihan dan lingkungan yang menunjang. Dalam menentukan teknik-teknik pelatihan dan pengembangan, timbul masalah mengenai trade-off. Oleh karena itu tidak ada teknik tunggal yang terbaik.

Metode pelatihan dan pengembangan terbaik tergantung dari beberapa faktor. Ada beberapa faktor yang perlu dipertimbangkan dan berperan dalam pelatihan dan pengembangan: (1) Cost-efectiveness (efektivitas biaya), (2) Materi program yang dibutuhkan, (3) Prinsip-prinsip pembelajaran, (4) Ketepatan dan kesesuaian fasilitas, (5) Kemampuan dan preferensi peserta pelatihan, dan (6) Kemampuan dan preferensi instruktur pelatihan.

\section{Komponen Pelatihan dan Pengembangan}

Menurut Mangkunegara, (2003) komponen-komponen pelatihan dan pengembangan:

a. Tujuan dan sasaran pelatihan pengembangan harus jelas dan terukur

b. Para pelatih (trainers) harus ahlinya yang berkualifikasi memadai (Profesional)

c. Materi pelatihan dan pengembangan harus disesuaikan dengan tujuan yang hendak dicapai.

d. Metode pelatihan dan pengembangan harus disesuaikan dengan tingkat kemampuan pegawai yang menjadi peserta

e. Peserta pelatihan dan pengembangan (trainers) harus memenuhi persyaratan yang ditentukan.

\subsection{Kepuasan Kerja}

Pengertian Kepuasan Kerja

Kepuasan kerja menurut Martoyo (1994), keadaan emosional karyawan di mana terjadi ataupun tidak terjadi titik temu antara nilai balas jasa kerja karyawan dari perusahaan/ organisasi dengan tingkat nilai balas jasa yang memang diinginkan oleh karyawan yang bersangkutan.

Kepuasan merupakan keadaan subyektif yang didasarkan pada perbandingan mengenai apa yang diterima pegawai dari pekerjaannya dibandingkan dengan yang diharapkan, diinginkan, dan dipikirkannya sebagai hal yang pantas atau berhak atasnya. Sementara setiap karyawan/ pegawai secara subyektif menentukan bagaimana pekerjaan itu memuaskan. Tiffin, (2000 dalam Moch. As'ad, 2004) berpendapat bahwa kepuasan kerja berhubungan erat dengan sikap dari karyawan terhadap pekerjaannya sendiri, situasi kerja, kerjasama antara pimpinan dengan karyawan.

\section{Teori-Teori Kepuasan Kerja}

Menurut Wexley dan Yulk, (1977 dalam Moch. As'ad, 2004) serta Kismono, (1999), teori-teori tentang kepuasan kerja yang dikenal yaitu: 


\section{Maret 2017}

\section{a. Fulfillment theory (teori pemenuhan)}

Menurut teori ini kepuasan kerja ialah fungsi dari kebutuhan. Kebutuhan di sinidiartikan sebagai kekurangan atau kekosongan batiniah yang bersifat psikologis dan phisiologis yang tidak dapat dipantau. Kekosongan batiniah ini diisi dan dengan demikian maka puaslah kerjanya.

b. Reward theority (teori imbalan)

Menurut teori ini kepuasan adalah fungsi dari imbalan yang diterima seseorang. Baik mengenai jumlahnya maupun kapan waktu diterimanya, berpengaruh terhadaptingkat kepuasannya. Seberapa besar kepuasannya tergantung pada penilaian yangdilakukan oleh penerimanya.

c. Discrepancy theory (teori kesenjangan)

Menurut teori ini kepuasan kerja dipengaruhi oleh harapan dari pekerja. Kepuasan kerja merupakan akibat dari perbandingan antara apa yang seharusnya diterima dan apa yang nyata diterima. Jika ia menerima lebih besar daripada yang diharapkan ia akan puas, sebaliknya jika menerima kurang dari yang diharapkan akan tidak puas.

d. Equity theory (teori keadilan)

Teori ini memperbandingkan seseorang dengan orang lain mengenai korban danhasil. Kepuasan kerja seseorang tergantung apakah ia merasakan keadilan atau tidak atas suatu situasi. Perasaan keadilan atau ketidakadilan atas suatu situasi diperoleh dengan membandingkan dirinya dengan orang lain yang sekelas, sekantor maupun di tempat lain.

Menurut teori ini, elemen-elemen dari equity ada tiga yaitu input, out comes dan comparation person (Wexley dan Yulk, 1977 dalam Moch. As'ad, 2004). Yang dimaksud dengan input adalah sesuatu yang berharga yang dirasakan pegawai/ karyawan sebagai sumbangan terhadap pekerjaannya, seperti pendidikan, pengalaman kerja, dan kecakapan. Out comes adalah sesuatu yang berharga yang dirasakan pegawai/ karyawan sebagai hasil dari pekerjaannya, seperti gaji, status, simbol, dan penghargaan. Comparation person adalah membandingkan input, out comes terhadap orang lain.

e. Two Factor Teory

Menurut two factor theory, kepuasan kerja itu merupakan dua hal yang berbeda, artinya kepuasan dan ketidakpuasan terhadap pekerjaan itu tidak merupakan suatu variabel kontinyu. Herzberg (dalam Moch. As'ad, 2004) membagi situasi yang mempengaruhi perasaan seseorang terhadap pekerjaannya menjadi dua kelompok yaitu kelompok satisfiers/ motivator yang terdiri dari prestasi, pengakuan, tanggungjawab. Dan yang kedua yaitu kelompok sebagai sumber ketidakpuasan atau dissatisfiers terdiri dari prosedur kerja, upah atau gaji, hubungan antar karyawan/ pegawai.

Faktor-Faktor yang dapat Menimbulkan Kepuasan Kerja

Pendapat Horald E.Burt (dalam Moch. As'ad, 2004) tentang faktor- faktor yang dapat menimbulkan kepuasan kerja sebagai berikut:

1) Faktor hubungan antar karyawan, antara lain hubungan antara pimpinan dengan pegawai, kondisi fisik dan situasi kerja, sugesti dari teman kerja.

2) Faktor individual, yang berhubungan dengan sikap orang terhadap pekerjaannya, umur orang saat kerja, jenis kelamin. 


\section{Maret 2017}

3) Faktor-faktor luar antara lain keadaan keluarga karyawan/ pegawai, rekreasi, pendidikan.

Faktor-faktor yang mempengaruhi kepuasan kerja menurut Gilmer (1966 dalam Moch. As'ad, 2004) adalah sebagai berikut:

a. Kesempatan untuk maju; Dalam hal ini ada tidaknya kesempatan untuk memperoleh peningkatan pengalaman dan kemampuan kerja.

b. Keamanan kerja; Faktor ini sering disebut sebagai penunjang kepuasan kerja, baik karyawan pria maupun wanita. Keadaan yang aman sangat mempengaruhi perasaan kerja karyawan selama bekerja.

c. Gaji; Gaji lebih banyak menyebabkan ketidakpuasan, dan jarang orang yang mengekspresikan kepuasan kerjanya dengan sejumlah uang yang diperolehnya.

d. Manajemen kerja; Manajemen kerja yang baik adalah yang memberikan situasi dan kondisi kerja yang stabil, sehingga karyawan dapat bekerja dengan nyaman.

e. Kondisi kerja; seperti tempat kerja, ventilasi, penyinaran, kantin, dan tempat parkir.

f. Pengawasan (Supervisi); Supervisi yang buruk dapat berakibat absensi dan turnover.

g. Faktor intrinsik dari pekerjaan; Atribut yang ada pada pekerjaan mensyaratkan ketrampilan tertentu. Sukar dan mudahnya serta kebanggaan akan tugas akan meningkatkan atau mengurangi kepuasan.

h. Komunikasi; Komunikasi yang lancar antara karyawan dengan pimpinan seperti adanya kesediaan pihak pimpinan untuk mau mendengar, memahami dan mengakui pendapat atau prestasi karyawannya sangat berperan dalam menimbulkan kepuasan kerja.

i. Aspek sosial dalam pekerjaan; Merupakan salah satu sikap yang sulit digambarkan tetapi dipandang sebagai faktor yang menunjang puas atau tidak puas dalam kerja

j. Fasilitas; Fasilitas rumah sakit, cuti, dana pensiun, atau perumahan merupakan standar suatu jabatan dan apabila dapat dipenuhi akan menimbulkan rasa puas.

Dari pendapat para ahli dapat disimpulkan bahwa faktor-faktor yang mempengaruhi kepuasan kerja (Sutrisno, 2015):

1) Faktor psikologis, merupakan faktor yang berhubungan dengan kejiwaan pegawai yang meliputi minat, ketentraman dalam kerja, sikap terhadap kerja, bakat dan keterampilan.

2) Faktor fisik, merupakan faktor yang berhubungan dengan kondisi fisik karyawan dan lingkungan kerja, meliputi jenis pekerjaan, pengaturan waktu kerja dan waktu istirahat, perlengkapan kerja, keadaan ruangan, suhu, penerangan, sirkulasi udara, kondisi kesehatan karyawan, umur.

3) Faktor finansial, merupakan faktor yang berhubungan dengan jaminan serta kesejahteraan karyawan, yang meliputi sistem penggajiandan besarnya gaji, jaminan sosial, macam-macam tunjangan, fasilitas yang diberikan, promosi, pengembangan.

4) Faktor sosial, merupakan faktor yang berhubungan dengan interaksi sosial baik antara sesama karyawan, dengan atasannya, maupun karyawan yang berbeda jenis pekerjaannya.

\section{Dimensi Kepuasan Kerja}

Menurut Luthan (2006) dimensi-dimensi kepuasan kerja adalah:

1. Pekerjaan itu sendiri, Pekerjaan memberikan tugas yang menarik, kesempatan untuk belajar, dan kesempatan menerima tanggung jawab. 
2. Gaji, Sejumlah upah yang diterima dan tingkat dimana hal ini bisa dipandang sebagai hal yang dianggap pantas dibandingkan dengan orang lain dalam organisasi.

3. Kesempatan promosi, Kesempatan untuk maju dalam organisasi

4. Pengawasan, Kemampuan penyelia untuk memberikan bantuan teknis dan dukungan perilaku.

5. Rekan kerja

\subsection{Produktivitas Kerja}

\section{Pengertian Produktivitas Kerja}

Produktivitas tenaga kerja adalah perbandingan antara hasil kerja yang di capai dengan peran serta tenaga kerja persatuan waktu (Kussriyanto, 1986). Menurut Melayu S.P. Hasibuan (1996) Produktivitas adalah perbandingan antara output (hasil) dengan input (masukan). Jika Produktivitas naik ini hanya dimungkinkan oleh adanya peningkatan efisiensi (waktu-bahan-tenaga), sisitem kerja, teknik produksi dan adanya peningkatan keterampilan dari tenaga kerjanya.

Produktivitas kerja merupakan suatu hasil kerja dari seseorang karyawan. Hasil kerja karyawan merupakan suatu proses bekerja dari seseorang dalam menghasilkan suatu barang dan jasa. Menurut Yuniarsih, et al., (2008) produktivitas kerja dapat diartikan sebagai hasil kongkrit (produk) yang dihasilkan oleh individu ataupun kelompok, selama satuan waktu tertentu dalam suatu proses kerja.

\section{Faktor-Faktor yang Mempengaruhi Produktivitas Kerja}

Menurut Simanjuntak (dalam Sutrisno, 2015) faktor yang dapat memengaruhi produktivitas kerja karyawan yaitu :

1. Pelatihan

Latihan kerja dimaksudkan untuk melengkapai karyawan dengan keterampilan dan cara-cara yang tepat untuk menggunakan peralatan kerja, mengerjakan pekerjaan dengan benar dan tepat, serta dapat memperkecil atau meninggalkan kesalahan-kesalahan yang pernah dilakukan. Stoner, (1991) mengemukakan bahwa peningkatan produktivitas bukan pada pemuktahiran peralatan, akan tetapi pada pengembangan karyawan yang paling utama. Dari hasil penelitian beliau menyebutkan $75 \%$ pengingkatan produktivitas justru dihasilkan oleh perbaikan pelatihan dan pengetahuan kerja, kesehatan dan alokasi tugas.

2. Mental dan kemampuan fisik karyawan.

Keadaan mental dan fisik karyawan merupakan hal penting menjadi perhatian organisasi, sebab keadaan fisik dan mental karyawan mempunyai hubungan yang sangat erat dengan produktivitas kerjanya.

3. Hubungan antara atasan dan bawahan.

Hubungan atasan dan bawahan akan memengaruhi kegiatan yang dilakukan sehari-sehari. Kerjasama dan perlakuan yang baik berdampakpada partisipasi tinggi karyawan dalam proses produksi, sehingga akan berpengaruh pada tingkat produktivitas kerja.

Menurut Ravianto (1998) menyebutkan bahwa faktor-faktor yang mempengaruhi produktivitas kerja pegawai meliputi pendidikan, keterampilan, disiplin, sikap dan etika kerja, motivasi, gaji, kesehatan, teknologi, manajemen dan kesempatan berprestasi. 


\section{Maret 2017}

Indikator Produktivitas Kerja

Menurut Sutrisno, (2015) untuk mengukur produktivitas kerja, diperlukan indikator:

1. Kemampuan

Kemampuan untuk melaksasnakan tugas sangat bergantung pada keterampilan yang dimiliki serta profesionalisme mereka dalam bekerja. Ini memberikan daya untuk menyelesaikan tugas-tugas yang diembannya kepada mereka.

2. Meningkatkan hasil yang dicapai.

Berusaha untuk meningkatkan hasil yang dicapai. Hasil merupakan salah satu yang dapat dirasakan baik oleh yang mengerjakan maupun yang menikmati hasil pekerjaan tersebut.

3. Semangat kerja

Ini merupakan usaha untuk lebih baik dari hari kemarin. Indikator ini dapat dillihat dari etos kerja dan hasil yang dicapai dalam satu hari kemudian dibandingkan dengan hari sebelumnya.

4. Pengembangan diri

Senantiasa mengembangkan diri untuk meningkatkan kemampuan kerja. pengembangan diri dapat dilakukan dengan melihat tantangan dan harapan dengan apa yang dihadapi. Sebab semakin kuat tantangannya, pengembangan diri mutlak dilakukan. Begitu juga harapan menjadi lebih baik akan sangat berdampak pada keingainan karyawan untuk meningkatkan kemampuan.

5. Mutu

Selalu berusaha untuk meningkatkan mutu lebih baik dari yang telah lalu. Mutu merupakan hasil pekerjaan yang dapat menunjukkan kualitas kerja seorang pegawai. Jadi, meningkatkan mutu bertujuan untuk memberikan hasil yang terbaik yang pada gilirannya akan sangat berguna bagi perusahaan dan dirinya sendiri.

Sedangkan menurut Siagian, (2010) indikator produktivitas kerja:

1. Kualitas hasil kerja karyawan, adalah kapasitas kerja dari karyawan yang diharapkan oleh perusahaan yang meliputi kemampuan karyawan dalam menyelesaikan tugas pekerjaan sesuai tidaknya hasil kerja denan standar yang berlaku di perusahaan. Kemampuan pegawai dalam melaksanakan pekerjaan dan tugasnya merupakan faktor yang sangat perlu agar diperoleh hasil yang diharapkan,

2. Kuantitas hasil kerja karyawan, adalah kemampuan dalam memenuhi standar perusahaan dalam bentuk jumlah barang yang dihasilkan,

3. Waktu dan kecepatan kerja karyawan untuk menyelesaikan pekerjaan. Kecepatan kerja karyawan, adalah suatu taraf pemahaman dalam melaksanakan tugasnya serta mengetahui kesulitan dalam melaksanakan tugasnya. Sedangkan ketepatan waktu yang digunakan karyawan dalam menyelesaikan tugas yang dibebankan mempengaruhi produktivitas kerja.

Menurut Sinungan, (2000) pengukuran Produktivitas Kerja dapat dilakukan dengan tiga cara salah satunya dengan melakukan perbandingan pelaksanaan sekarang dengan targetnya, dan inilah yang terbaik, sebab memusatkan perhatian pada sasaran atau tujuan. 
4. Kerangka Teoritis

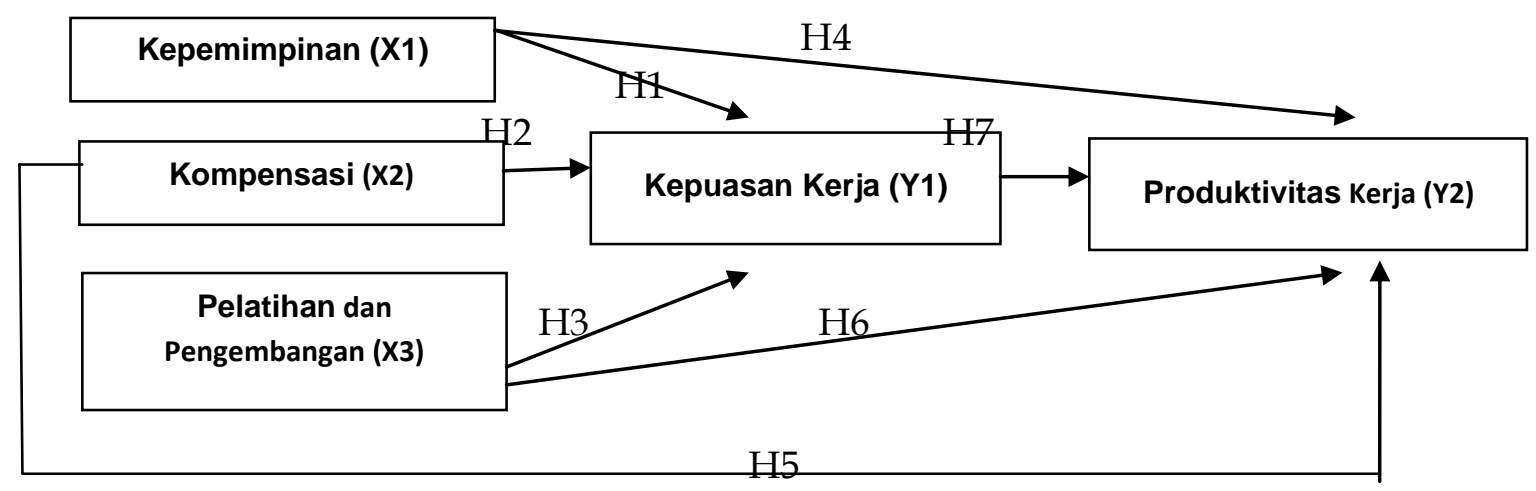

Gambar 2.1. Kerangka Teoritis Penelitian

\section{Hipotesis}

H1=Kepemimpinan berpengaruh positif dan signifikan terhadap Kepuasan Kerja

$\mathrm{H} 2=$ Kompensasi berpengaruh positif dan signifikan terhadap Kepuasan

H3=Pelatihan dan Pengembangan berpengaruh positif dan signifikan terhadap Kepuasan Kerja

H4=Kepemimpinan berpengaruh positif dan signifikan terhadap Produktivitas Kerja

H5=Kompensasi berpengaruh positif dan signifikan terhadap Produktivitas Kerja

H6=Pelatihan dan Pengembangan berpengaruh positif dan signifikan terhadap Produktivitas Kerja

H7=Kepuasan Kerja berpengaruh positif dan signifikan terhadap Produktivitas Kerja

\section{Metode Penelitian}

Penelitian ini merupakan penelitian kuantitatif yang berdasarkan tingkat eksplanasinya (tingkat kejelasannya) penelitian ini adalah penelitian asosiatif. Penelitian asosiatif merupakan penelitian yang bertujuan untuk mengetahui pengaruh ataupun juga hubungan antara dua variabel atau lebih (Sugiyono, 2014) Penelitian ini menganalisis hubungan antar variabel yang berbetuk hubungan kausal (hubungan yang bersifat sebab akibat) (Sugiyono, 2014). Penelitian ini bertujuan untuk mengetahui pengaruh kepemimpinan, kompensasi, pelatihan dan pengembangan terhadap kepuasan kerja dan produktivitas kerja PNS BPN NTB.

Populasi penelitian adalah PNS BPN NTB yang berjumlah 465 orang. Teknik sampling yang digunakan adalah metoda Non-Probability Sampling/ Non random sampel dengan Purposive Sampling. Responden ditetapkan dengan kriteria-kriteria yakni merupakan PNS BPN NTB yang telah bekerja minimal 5 tahun dan menjabat sebagai Kepala Seksi/ Kepala Sub Bagian (Eselon IV) di tingkat Kantor Wilayah dan Kantor Pertanahan Kabupaten/ Kota berjumlah 79 orang.

Teknik pengumpulan data melalui angket dan dokumentasi. Alat pengumpulan data yang digunakan adalah kuesioner. Kuesioner dalam peneitian ini diadopsi dari beberapa jurnal yang ditulis oleh Celluci, Anthony dan David (1978) tentang Kuesioner Kepuasan Kerja (Measuring Managerial Satisfaction) dan penelitian Siba (2015), Kuesioner Produktivitas Kerja/ Job Performance oleh Jansen dan One (2001), Kuesioner tentang Gaya Kepemimpinan dari penelitian Reinhat (2012) dan Supatmi, et, al., (2013), Kuesioner 


\section{TMM JURNAL MAGISTER MANAJEMEN UNIVERSITAS MATARAM UNRAM \\ Maret 2017}

tentang Kompensasi dari penelitian Apriyani, 2013, dan Kuesioner Pelatihan dan Pengembangan penelitian Suwendra, et.al, 2016.

Pengisian kuesioner dengan cara mengirimkan kuesioner lewat jasa pos ke masingmasing kantor tempat responden bekerja untuk selanjutnya diisi oleh responden. Analisa data statistik dan pengujian hipotesis menggunakan teknik analisa data dengan pendekan Partial Least Square (PLS). Metode PLS dengan software SmartPLS versi 3.

7. Hasil Analisa Data dengan Metode Partial Least Square (PLS)

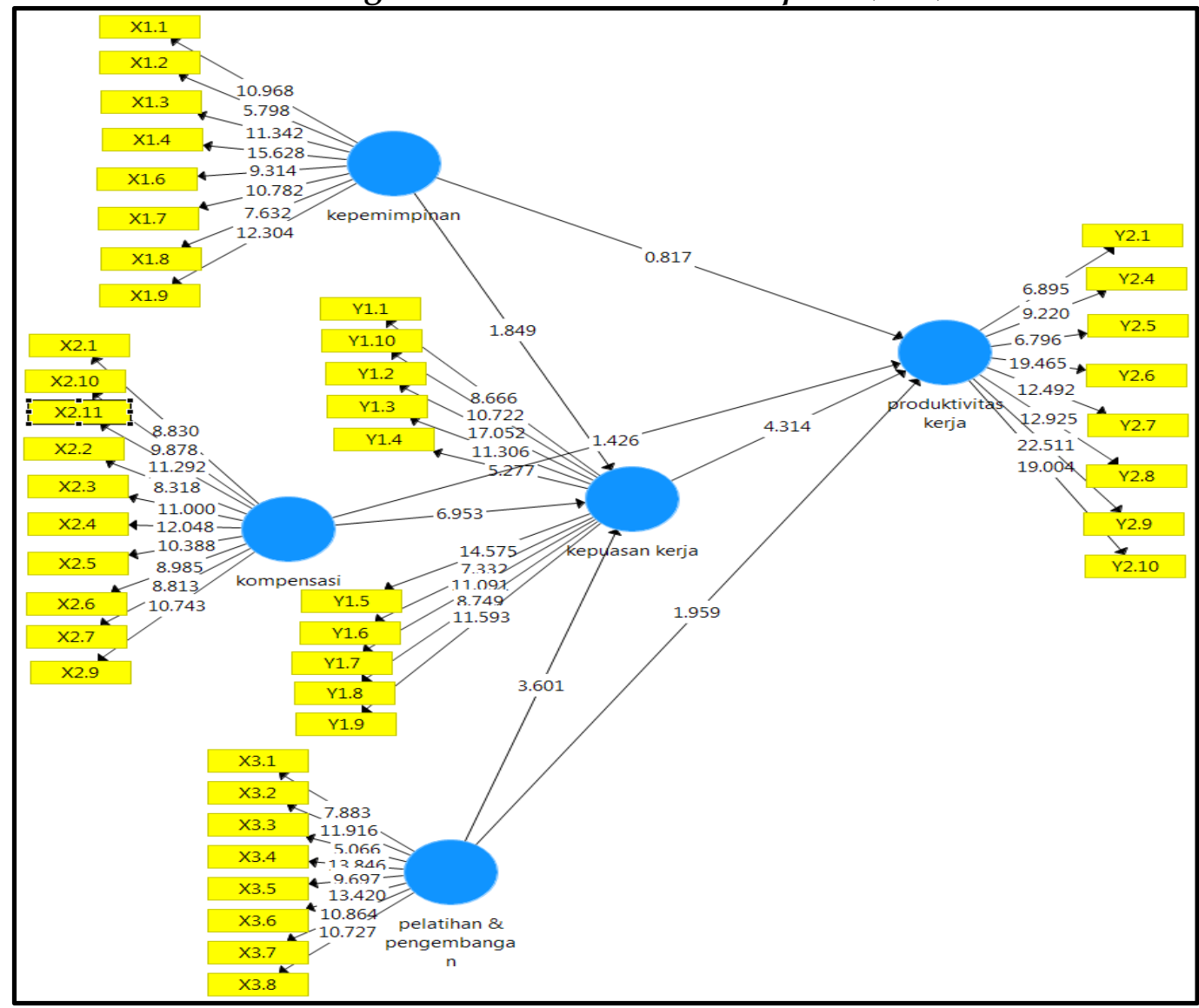

Gambar 4.8. Diagram Jalur Permodelan 3

\section{Hasil Konversi Diagram Jalur Kedalam Sistem Persamaan}

Hasil konversi diagram jalur kedalam sistem persamaan bertujuan untuk mengetahui barapakah nilai dari besarnya pengaruh antara variabel laten dan indikatronya. Pada penelitian ini terdapat dua model persamaan yaitu :

\section{Persamaan Model Struktural}

Persamaan-persamaan yang didapat dari hasil diagram jalur permodelan 3 yakni :

$\mathrm{Y} 1=1,849 \times 1+6,953 \mathrm{X} 2+3,601 \times 3+s_{j}$

Setiap variabel laten eksogen mempunyai pengaruh positif terhadap laten endogen. Faktor kepemimpinan berpengaruh positif terhadap kepuasan kerja dengan nilai sebesar 1,849, faktor kompensasi dengan nilai 6,953 dan faktor pelatihan dan pengembangan dengan nilai 3,601. Faktor kompensasi paling dominan berpengaruh terhadap kepuasan kerja pegawai BPN NTB.

$\mathrm{Y} 2=0,817 \mathrm{X} 1+1,426 \times 2+1,959 \times 3+\mathrm{s}_{j}$ 


\section{Maret 2017}

Setiap variabel laten eksogen mempunyai pengaruh positif terhadap laten endogen. Faktor kepemimpinan berpengaruh positif terhadap produktivitas kerja dengan nilai sebesar 0,817, faktor kompensasi dengan nilai 1,426 dan faktor pelatihan dan pengembangan dengan nilai 1,959. Faktor pelatihan dan pengembangan berpengaruh paling dominan terhadap produktivitas kerja pegawai BPN NTB.

$\mathrm{Y} 2=4,314 \mathrm{Y} 1+\mathrm{S} \mathrm{j}$

Variabel laten endogen Kepuasan Kerja berpengaruh positif terhadap Produktivitas Kerja dengan nilai 4,314. Faktor kepuasan kerja berpengaruh besar terhadap produktivitas kerja pegawai BPN NTB.

\section{Persamaan Model Pengukuran}

a. Variabel Kepemimpinan (X1)

Penelitian ini terdiri dari sembilan indikator yaitu kejelasan pengarahan (X11), rutinitas pengarahan (X12), efektivitas komunikasi (X13), komunikasi menumbuhkan semangat dan loyalitas (X14), pembagian kewenangan dan tanggung jawab (X15), kewenangan yang dibatasi (X16), efektivitas motivasi (X17), profesionalitas pengawasan (X18), rutinitas evaluasi (X19).

Setelah dilakukan pengolahan data dengan SmartPLS diketahui indikator pembagian kewenangan dan tanggung jawab (X15) mempunyai nilai < 0,50 sehingga dilakukan eliminasi. Hubungan antara variabel kepemimpinan dengan indikatornya yaitu :

$$
\begin{gathered}
X 1=10,968 X 11+5,798 \times 12+11,342 \times 13+15,628 \times 14+ \\
9,314 X 16+10,782 X 17+7,632 X 18+12,304 X 19
\end{gathered}
$$

Dari kedelapan indikator tersebut, dapat dilihat bahwa indikator komunikasi menumbuhkan semangat dan loyalitas (X14) memiliki nilai yang paling tinggi yaitu 15,628, artinya indikator tersebut berpengaruh paling banyak terhadap variabel kepemimpinan. Hal ini berarti komunikasi yang baik yang dilakukan atasan merupakan indikator yang dianggap paling penting mempengaruhi keefektivitasan kepemimpinan sehingga mampu menumbuhkan semangat kerjasama dan loyalitas dari para pegawai.

b. Variabel Kompensasi (X2)

Variabel ini terdiri dari sebelas indikator yaitu keadilan kompensasi finansial langsung (X21), keadilan insentif/ penghasilan tambahan (X22),

kelayakan kompensasi finansial langsung (X23), ketepatan waktu pemberian kompensasi finansial langsung (X24), keadilan dan kelayakan kompensasi finansial tidak langsung (X25), kemudahan memperoleh cuti-cuti (X26), rutinitas diklat (X27), variasi tugas (X28), peluang promosi terbuka (X29), penghargaan terhadap hasil dan prestasi kerja (X210), kenyamanan lingkungan kerja (X211)

Setelah dilakukan modifikasi diketahui indikator variasi tugas (X28) memiliki nilai outer loading $<0,5$ sehingga dilakukan eliminasi. Hubungan kompensasi dengan indikatornya yaitu :

$$
\begin{gathered}
X 2=8,830 \times 21+8,318 \times 22+11,000 \times 23+12,048 \times 24+ \\
10,388 \times 25+8,985 \times 26+8,813 \times 27+10,743 \times 29+ \\
9,878 \times 210+11,292 \times 211
\end{gathered}
$$

Dari kesepuluh indikator tersebut, dapat diketahui indikator ketepatan waktu pemberian kompensasi finansial langsung (X24) memiliki nilai yang paling tinggi sebesar 12,048, artinya indikator gaji, tunjangan-tunjangan, tunjangan kinerja 
dan penghasilan tambahan (honor, pembagian hasil kerja, lumsum perjalanan dinas) yang diberikan tepat waktu berpengaruh paling banyak terhadap kompensasi. Hal tersebut mampu mewujudkan keadilan dan kelayakan kompensasi yang diterima pegawai BPN NTB.

c. Variabel Pelatihan dan Pengembangan (X3)

Variabel ini memiliki delapan indikator yaitu keantusiasan peserta diklat (X31), profesionalitas pelatih diklat (X32), kesesuaian materi diklat dengan kebutuhan pekerjaan (X33), keefektifan metode diklat (X34), penerapan materi diklat dalam pekerjaan (X35), materi diklat yang aplikatif (X36), diklat meningkatkan kompetensi (X37), pencapaian tujuan dan sasaran diklat (X38). Hubungan pelatihan dan pengembangan terhadap indikatornya :

$$
\begin{array}{r}
\mathrm{X} 3=7,883 \times 31+11,916 \times 32+5,066 \times 33+13,846 \times 34+ \\
9,697 X 35+13,420 \times 36+10,864 X 37+10,727 \text { X38 }
\end{array}
$$

Dari kedelapan indikator tersebut, dapat diketahui indikator keefektifan metode diklat (X34) dan materi diklat yang aplikatif (X36) memiliki nilai yang paling tinggi yaitu sebesar 13,846 dan 13,420. Hal ini memberi gambaran bahwa metode diklat efektif memudahkan peserta memahami materi diklat dan materi diklat yang diberikan dapat diaplikasikan dalam pekerjaan/ mendukung pekerjaan.

d. Variabel Kepuasan Kerja (Y1)

Variabel ini memiliki sepuluh indikator yaitu kelayakan dan ketepatan waktu kompensasi finansial langsung (Y11), keadilan kompensasi finansial langsung (Y12), ketepatan jabatan dengan spesifikasi pekerjaan (Y13), ketepatan penempatan posisi kerja (Y14), keamanan, kenyamanan dan kebersihan lingkungan kerja (Y15), dukungan dan kerjasama rekan-rekan kerja (Y16), rutinitas bimbingan kerja dari atasan (Y17), kedekatan dengan atasan (Y18), penghargaan dari atasan (Y19), tingkat kesenangan dalam bekerja (Y10). Hubungan variabel kepuasan kerja dengan indikatornya yaitu :

$$
\begin{aligned}
\mathrm{Y} 1= & 8,666 \mathrm{Y} 11+17,052 \mathrm{Y} 12+11,306 \mathrm{Y} 13+5,277 \mathrm{Y} 14+ \\
& 14,575 \mathrm{Y} 15+7,332 \mathrm{Y} 16+11,091 \mathrm{Y} 17+8,749 \mathrm{Y} 18+ \\
& 11,593 \mathrm{Y} 19+10,722 \mathrm{Y} 110
\end{aligned}
$$

Dari kesepuluh indikator tersebut dapat diketahui bahwa indikator keadilan kompensasi finansial langsung (Y12) memiliki nilai yang paling tinggi yakni 17,052, artinya indikator tersebut berpengaruh paling banyak terhadap variabel kepuasan kerja. Besaran gaji dan tunjangan-tunjangan yang diterima pegawai BPN NTB telah sesuai dengan jabatan dan beban kerja yang diemban/ memenuhi asas keadilan sehingga tercipta kepuasan terhadap kompensasi yang berdampak pada kepuasan kerja para pegawainya.

e. Variabel Produktivitas Kerja (Y2)

Variabel ini memiliki sepuluh indikator yakni pencapaian target kerja (Y21), tingkat kuantitas kerja (Y22), tingkat kualitas kerja (Y23), ketepatan waktu penyelesaian pekerjaan (Y24), efektifitas perencanaan dan konsistensi pelaksanaan (Y25), evaluasi dan rutinitas laporan kepada atasan (Y26), keajegan menaati peraturan perundang-undangan (Y27), efektivitas kerjasama dengan rekan kerja dan bawahan (Y28), tingkat pengembangan diri (Y29), tingkat kreatifitas dan inovasi (Y210). 
Setelah dilakukan pengolahan data dengan smartPLS diketahui indikator Y22 dan Y23 mempunyai nilai outer loading < 0,5 sehingga dilakukan eliminasi. Hubungan antara variabel produktivitas kerja dengan indikatornya yaitu :

$$
\begin{array}{r}
\mathrm{Y} 2=6,895 \mathrm{Y} 21+9,220 \mathrm{Y} 24+6,796 \mathrm{Y} 25+19,465 \mathrm{Y} 26+ \\
12,492 \mathrm{Y} 27+12,925 \mathrm{Y} 28+22,511 \mathrm{Y} 29+19,004 \mathrm{Y} 210
\end{array}
$$

Dari kedelapan indikator tersebut dapat dilihat bahwa indikator tingkat pengembangan diri (Y29) dan evaluasi dan rutinitas laporan kepada atasan (Y26) memiliki nilai tertinggi yakni 22,511 dan 19,465. Artinya indikator tersebut berpengaruh paling banyak terhadap variabel produktivitas kerja. Hal ini berarti para pegawai BPN senantiasa selalu berusaha menjadi lebih baik dalam bekerja dan selalu melakukan evaluasi atas pekerjaan dan rutin melaporkannya kepada atasan agar mencapai produktivitas kerja yang tinggi.

\section{Goodness of Fit} Inner Model

Pengujian inner model atau model struktural dilakukan untuk melihat hubungan antara variabel, nilai signifikansi dan $R$ Square $\left(R^{2}\right)$ dari model penelitian. Model struktural di evaluasi dengan menggunakan $R$ Square $\left(R^{2}\right)$ untuk variabel dependen, uji serta signifikansi dari koefisien parameter jalur struktural. Untuk mendapatkan nilai uji masing-masing komponen tersebut dilakukan dengan melihat hasil proses bootstrapping dan akan ditunjukan nilai masing-masing konstruk untuk tiap parameter.

Pengujian goodness of fit model struktural inner model menggunakan nilai $R$ Square $\left(R^{2}\right), R^{2}$ berfungsi melihat nilai signifikansi dari variabel laten (Sheng, 2006). Nilai $R$ Square dapat dilihat pada Tabel 4.16.

Tabel 4.16. Nilai $R$ Square

\begin{tabular}{|l|c|}
\hline & R Square \\
\hline $\begin{array}{l}\text { Kepuasan Kerja } \\
\text { (Y1) }\end{array}$ & 0,748 \\
\hline $\begin{array}{l}\text { Produktivitas } \\
\text { (Y2) }\end{array}$ & 0,684 \\
\hline
\end{tabular}

Sumber : Data Primer diolah (Lampiran)

Pada penelitian ini didapatkan hasil nilai $\mathrm{R}^{2}$ variabel kepuasan kerja adalah 0,748 yang artinya variabel kepemimpinan, kompensasi, pelatihan dan pengembangan mampu menjelaskan variabel kepuasan kerja sebesar $74,8 \%$ sedangkan sisanya dijelaskan oleh variabel lain di luar model penelitian. Begitu pula dengan nilai $\mathrm{R}^{2}$ variabel produktivitas kerja adalah 0,684 yang artinya variabel kepemimpinan, kompensasi, pelatihan pengembangan dan kepuasan kerja mampu menjelaskan variabel produktivitas kerja sebesar $68,4 \%$ sedangkan sisanya dijelaskan oleh variabel lain di luar model penelitian. Hal ini mengindikasikan bahwa model yang dibentuk pada penelitian ini telah baik.

\section{Outer Model}

a. Convergent Validity

Menurut Ingrati dkk (2012), convergent validity dilakukan untuk menguji setiap indikator dalam variabel laten dan memastikan bahwa indikator yang digunakan dapat dipahami responden dengan baik apabila diperoleh nilai loading factor $>0,5$. Nilai convergent validity dapat dilihat pada tabel 4.17.

Tabel 4.17 Nilai Convergent Validity 


\section{TMM JURNAL MAGISTER MANAJEMEN UNIVERSITAS MATARAM UNRAM \\ Maret 2017}

\begin{tabular}{|c|c|c|c|}
\hline Variabel & Indikator & $\begin{array}{c}\text { Convergent } \\
\text { Validity }\end{array}$ & Kategori \\
\hline \multirow{8}{*}{$\begin{array}{l}\text { Kepemimpinan } \\
(\mathrm{X} 1)\end{array}$} & $\mathrm{X} 11$ & 0,701 & Valid \\
\hline & $\mathrm{X} 12$ & 0,537 & Valid \\
\hline & X13 & 0,705 & Valid \\
\hline & X14 & 0,780 & Valid \\
\hline & X16 & 0,693 & Valid \\
\hline & X17 & 0,727 & Valid \\
\hline & X18 & 0,697 & Valid \\
\hline & X19 & 0,719 & Valid \\
\hline \multirow[t]{10}{*}{ Kompensasi (X2) } & $\mathrm{X} 21$ & 0,633 & Valid \\
\hline & $\mathrm{X} 22$ & 0,663 & Valid \\
\hline & $\mathrm{X} 23$ & 0,714 & Valid \\
\hline & $\mathrm{X} 24$ & 0,754 & Valid \\
\hline & X25 & 0,697 & Valid \\
\hline & $X 26$ & 0,623 & Valid \\
\hline & $\mathrm{X} 27$ & 0,643 & Valid \\
\hline & X29 & 0,733 & Valid \\
\hline & $X 210$ & 0,708 & Valid \\
\hline & $\mathrm{X} 211$ & 0,682 & Valid \\
\hline \multirow{8}{*}{$\begin{array}{l}\text { Pelatihan dan } \\
\text { Pengembangan } \\
\text { (X3) }\end{array}$} & X31 & 0,705 & Valid \\
\hline & X32 & 0,736 & Valid \\
\hline & X33 & 0,599 & Valid \\
\hline & X34 & 0,771 & Valid \\
\hline & X35 & 0,712 & Valid \\
\hline & X36 & 0,723 & Valid \\
\hline & X37 & 0,702 & Valid \\
\hline & $\mathrm{X} 38$ & 0,714 & Valid \\
\hline \multirow{10}{*}{$\begin{array}{l}\text { Kepuasan Kerja } \\
\text { (Y1) }\end{array}$} & Y11 & 0,623 & Valid \\
\hline & Y12 & 0,787 & Valid \\
\hline & Y13 & 0,698 & Valid \\
\hline & Y14 & 0,559 & Valid \\
\hline & Y15 & 0,736 & Valid \\
\hline & Y16 & 0,584 & Valid \\
\hline & Y17 & 0,768 & Valid \\
\hline & Y18 & 0,667 & Valid \\
\hline & Y19 & 0,737 & Valid \\
\hline & Y110 & 0,716 & Valid \\
\hline \multirow{8}{*}{$\begin{array}{l}\text { Produktivitas } \\
\text { Kerja (Y2) }\end{array}$} & Y21 & 0,653 & Valid \\
\hline & Y24 & 0,711 & Valid \\
\hline & Y25 & 0,649 & Valid \\
\hline & Y26 & 0,802 & Valid \\
\hline & Y27 & 0,714 & Valid \\
\hline & Y28 & 0,736 & Valid \\
\hline & Y29 & 0,807 & Valid \\
\hline & Y210 & 0,775 & Valid \\
\hline
\end{tabular}

Sumber : Data Primer diolah (Lampiran) 


\section{Maret 2017}

Berdasarkan Tabel 4.17 semua indikator yang berjumlah empat puluh empat (44) memenuhi convergent validity karena memiliki nilai loading factor di atas 0,5 hal ini menunjukan semua indikator valid dan dapat digunakan sebagai pengukur variabel konstruk yang dituju dan memenuhi kriteria untuk diikutsertakan dalam analisis selanjutnya.

\section{b. Discriminant Validity}

Discriminant validity dilakukan untuk memastikan bahwa setiap konsep dari masing-masing variable laten berbeda dengan variabel lainnya. Model dikatakan mempunyai discriminant validity yang baik jika setiap nilai loading indikator dari sebuah variabel laten memiliki nilai loading yang lebih besar dibanding nilai loading jika dikorelasikan dengan variabel laten lainnya.

Didapatkan dari nilai cross loading setiap indikator pada variabelnya. Jika nilai discriminant validity $>0,5$ maka variabel laten tersebut mampu menjadi pembanding yang baik untuk model. Hasil discriminant validity pada penelitian ini dapat dilihat pada Tabel 4.18.

Tabel 4.18. Nilai Discriminant Validity

\begin{tabular}{|c|c|c|c|c|c|}
\hline & $\begin{array}{c}\text { Kepemimpi } \\
\text { nan }\end{array}$ & $\begin{array}{c}\text { Kompensa } \\
\text { si }\end{array}$ & $\begin{array}{c}\text { Pelatihan } \\
\text { dan } \\
\text { Pengembang } \\
\text { an }\end{array}$ & $\begin{array}{c}\text { Kepuas } \\
\text { an } \\
\text { Kerja }\end{array}$ & $\begin{array}{c}\text { Produktiv } \\
\text { itas } \\
\text { Kerja }\end{array}$ \\
\hline X11 & $\mathbf{0 . 7 0 1}$ & 0.522 & 0.297 & 0.491 & 0.375 \\
\hline X12 & $\mathbf{0 . 5 3 7}$ & 0.317 & 0.264 & 0.235 & 0.271 \\
\hline X13 & $\mathbf{0 . 7 0 5}$ & 0.536 & 0.411 & 0.533 & 0.414 \\
\hline X14 & $\mathbf{0 . 7 8 0}$ & 0.491 & 0.445 & 0.534 & 0.469 \\
\hline X16 & $\mathbf{0 . 6 9 3}$ & 0.441 & 0.374 & 0.394 & 0.313 \\
\hline X17 & $\mathbf{0 . 7 2 7}$ & 0.562 & 0.355 & 0.547 & 0.432 \\
\hline X18 & $\mathbf{0 . 6 9 7}$ & 0.505 & 0.429 & 0.507 & 0.458 \\
\hline X19 & $\mathbf{0 . 7 1 9}$ & 0.570 & 0.520 & 0.559 & 0.521 \\
\hline X21 & 0.434 & $\mathbf{0 . 6 3 3}$ & 0.340 & 0.498 & 0.377 \\
\hline X22 & 0.494 & $\mathbf{0 . 6 6 3}$ & 0.366 & 0.494 & 0.379 \\
\hline X23 & 0.513 & $\mathbf{0 . 7 1 4}$ & 0.382 & 0.513 & 0.438 \\
\hline X24 & 0.455 & $\mathbf{0 . 7 5 4}$ & 0.348 & 0.455 & 0.271 \\
\hline X25 & 0.454 & $\mathbf{0 . 6 9 7}$ & 0.524 & 0.454 & 0.470 \\
\hline X26 & 0.491 & $\mathbf{0 . 6 2 3}$ & 0.317 & 0.491 & 0.471 \\
\hline X27 & 0.522 & $\mathbf{0 . 6 4 3}$ & 0.428 & 0.522 & 0.385 \\
\hline X29 & 0.506 & $\mathbf{0 . 7 3 3}$ & 0.377 & 0.506 & 0.407 \\
\hline X210 & 0.491 & $\mathbf{0 . 7 0 8}$ & 0.369 & 0.555 & 0.330 \\
\hline X211 & 0.547 & $\mathbf{0 . 6 8 2}$ & 0.523 & 0.680 & 0.523 \\
\hline X31 & 0.388 & 0.371 & $\mathbf{0 . 7 0 5}$ & 0.491 & 0.483 \\
\hline X32 & 0.429 & 0.468 & $\mathbf{0 . 7 3 6}$ & 0.543 & 0.479 \\
\hline X33 & 0.293 & 0.359 & $\mathbf{0 . 5 9 9}$ & 0.477 & 0.403 \\
\hline X34 & 0.493 & 0.504 & $\mathbf{0 . 7 7 1}$ & 0.525 & 0.515 \\
\hline X35 & 0.409 & 0.340 & $\mathbf{0 . 7 1 2}$ & 0.517 & 0.479 \\
\hline X36 & 0.484 & 0.549 & $\mathbf{0 . 7 2 3}$ & 0.577 & 0.579 \\
\hline X37 & 0.363 & 0.302 & $\mathbf{0 . 7 0 2}$ & 0.462 & 0.597 \\
\hline X38 & 0.312 & 0.426 & $\mathbf{0 . 7 1 4}$ & 0.461 & 0.447 \\
\hline & & & & & \\
\hline
\end{tabular}




\section{Maret 2017}

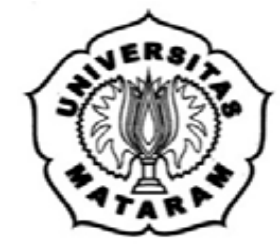

\begin{tabular}{|c|l|l|l|l|l|}
\hline Y11 & 0.518 & 0.589 & 0.393 & $\mathbf{0 . 6 2 3}$ & 0.434 \\
\hline Y12 & 0.532 & 0.703 & 0.589 & $\mathbf{0 . 7 8 7}$ & 0.602 \\
\hline Y13 & 0.425 & 0.542 & 0.536 & $\mathbf{0 . 6 9 8}$ & 0.556 \\
\hline Y14 & 0.176 & 0.318 & 0.321 & $\mathbf{0 . 5 5 9}$ & 0.387 \\
\hline Y15 & 0.598 & 0.628 & 0.643 & $\mathbf{0 . 7 3 6}$ & 0.627 \\
\hline Y16 & 0.426 & 0.417 & 0.382 & $\mathbf{0 . 5 8 4}$ & 0.615 \\
\hline Y17 & 0.600 & 0.654 & 0.474 & $\mathbf{0 . 7 6 8}$ & 0.602 \\
\hline Y18 & 0.490 & 0.526 & 0.470 & $\mathbf{0 . 6 6 7}$ & 0.540 \\
\hline Y19 & 0.553 & 0.600 & 0.523 & $\mathbf{0 . 7 3 7}$ & 0.553 \\
\hline Y110 & 0.414 & 0.482 & 0.546 & $\mathbf{0 . 7 1 6}$ & 0.556 \\
\hline Y21 & 0.376 & 0.443 & 0.365 & 0.509 & $\mathbf{0 . 6 5 3}$ \\
\hline Y24 & 0.396 & 0.415 & 0.456 & 0.501 & $\mathbf{0 . 7 1 1}$ \\
\hline Y25 & 0.417 & 0.364 & 0.481 & 0.532 & $\mathbf{0 . 6 4 9}$ \\
\hline Y26 & 0.526 & 0.517 & 0.559 & 0.676 & $\mathbf{0 . 8 0 2}$ \\
\hline Y27 & 0.488 & 0.315 & 0.563 & 0.476 & $\mathbf{0 . 7 1 4}$ \\
\hline Y28 & 0.412 & 0.496 & 0.525 & 0.651 & $\mathbf{0 . 7 3 6}$ \\
\hline Y29 & 0.425 & 0.430 & 0.608 & 0.633 & $\mathbf{0 . 8 0 7}$ \\
\hline Y210 & 0.454 & 0.528 & 0.555 & 0.660 & $\mathbf{0 . 7 7 5}$ \\
\hline S
\end{tabular}

Sumber : Data Primer diolah (Lampiran)

Berdasarkan pada Tabel 4.18 di atas menunjukan bahwa nilai loading dari masing-masing item terhadap konstruknya lebih besar dari nilai cross loadingnya. Dari hasil analisa cross loading tampak bahwa tidak terdapat permasalahan discriminant validity atau dengan kata lain dapat dikatakan data memiliki discriminant validity yang baik.

c. Composite Reliability

Seluruh variabel laten memiliki tingkat reliabel yang konsisten. Karena seluruh nilai composite reliability memiliki nilai yang $>0,6$. Hasil pengujian composite reliability dapat dilihat pada Tabel 4.19 .

Tabel 4.19. Nilai Composite Reliability

\begin{tabular}{|l|c|c|}
\hline Variable Penelitian & $\begin{array}{c}\text { Composite } \\
\text { Reliability }\end{array}$ & Kriteria \\
\hline Kepemimpinan (X1) & 0,883 & Reliabel \\
\hline Kompensasi (X2) & 0,899 & Reliabel \\
\hline $\begin{array}{l}\text { Pelatihan dan } \\
\text { Pengembangan (X3) }\end{array}$ & 0,890 & Reliabel \\
\hline Kepuasan Kerja (Y1) & 0,901 & Reliabel \\
\hline $\begin{array}{l}\text { Produktivitas Kerja } \\
(Y 2)\end{array}$ & 0,902 & Reliabel \\
\hline
\end{tabular}

Sumber : Data Primer diolah (Lampiran)

Tabel 4.19 menginformasikan bahwa seluruh variabel memenuhi composite reliability karena nilainya di atas angka yang direkomendasikan, yaitu di atas 0,6 yang berarti bahwa seluruh variabel sudah memenuhi kriteria reliabel.

Berdasarkan dari hasil evaluasi secara keseluruhan, baik convergent validity, discriminant validity, dan composite reliability yang telah dipaparkan di atas, maka disimpulkan bahwa indikator-indikator sebagai pengukur variabel laten merupakan pengukur yang valid dan reliabel. 


\section{Maret 2017}

\section{Uji Hipotesis}

Signifikansi parameter yang diestimasi memberikan informasi yang sangat berguna mengenai hubungan antara variabel-variabel penelitian. Dasar yang digunakan dalam menguji hipotesis adalah nilai yang terdapat pada output path coeffecients.

Pengujian hipotesis dilakukan dengan membandingkan t-statistik dengan t-tabel. Jika nilai t-statistik < nilai t-tabel berarti variabel eksogen tidak berpengaruh terhadap variabel endogen. Apabila t-statistik $>$ nilai $\mathrm{t}$-tabel berarti variabel eksogen berpengaruh terhadap variabel endogen, sehingga dapat dikatakan hipotesis diterima. Nilai t-tabel dan t-statistik dapat dilihat pada Tabel 4.20.

Tabel 4.20. Hasil Uji Hipotesis

\begin{tabular}{|c|c|c|c|c|}
\hline Hipotesis Statistik & $\begin{array}{l}\text { Original } \\
\text { Sampel } \\
(\mathrm{O})\end{array}$ & $\begin{array}{c}\mathrm{T} \\
\text { Statistik } \\
\text { (STERR) }\end{array}$ & T Tabel & Keterangan \\
\hline $\begin{array}{l}\text { Kepemimpinan-> kepuasan } \\
\text { kerja } \\
(\text { Hipotesis } 1)\end{array}$ & 0,157 & 1,849 & 1,96 & $\begin{array}{c}\text { Tidak } \\
\text { berpengaruh } \\
\text { signifikan } \\
\end{array}$ \\
\hline $\begin{array}{l}\text { Kompensasi-> kepuasan } \\
\text { kerja } \\
\text { (Hipotesis 2) }\end{array}$ & 0,492 & 6,953 & 1,96 & $\begin{array}{c}\text { Berpengaruh } \\
\text { signifikan }\end{array}$ \\
\hline $\begin{array}{l}\text { Pelatihan \& Pengembangan } \\
->\text { kepuasan kerja } \\
\text { (Hipotesis 3) }\end{array}$ & 0,339 & 3,601 & 1,96 & $\begin{array}{c}\text { Berpengaruh } \\
\text { signifikan }\end{array}$ \\
\hline $\begin{array}{l}\text { Kepemimpinan-> } \\
\text { produktivitas kerja } \\
\text { (Hipotesis } 4 \text { ) }\end{array}$ & 0,090 & 0,817 & 1,96 & $\begin{array}{l}\text { Tidak } \\
\text { berpengaruh } \\
\text { signifikan }\end{array}$ \\
\hline $\begin{array}{l}\text { Kompensasi -> } \\
\text { produktivitas kerja } \\
\text { (Hipotesis 5) }\end{array}$ & $-0,162$ & 1,426 & 1,96 & $\begin{array}{c}\text { Tidak } \\
\text { berpengaruh } \\
\text { signifikan }\end{array}$ \\
\hline $\begin{array}{l}\text { Pelatihan \& Pengembangan } \\
\text {-> produktivitas kerja } \\
\text { (Hipotesis 6) }\end{array}$ & 0,271 & 1,959 & 1,96 & $\begin{array}{c}\text { Tidak } \\
\text { berpengaruh } \\
\text { signifikan } \\
\end{array}$ \\
\hline $\begin{array}{l}\text { Kepuasan kerja -> } \\
\text { Produktivitas Kerja } \\
\text { (Hipotesis 7) }\end{array}$ & 0,672 & 4,314 & 1,96 & $\begin{array}{c}\text { Berpengaruh } \\
\text { signifikan }\end{array}$ \\
\hline
\end{tabular}

Sumber : Data Primer diolah (Lampiran)

Tabel di atas menunjukan bahwa hubungan antara kepemimpinan dengan kepuasan kerja adalah tidak berpengaruh signifikan dengan t-statistik sebesar 1,849 $(<1,96)$. Nilai original sample estimate adalah positif yaitu sebesar 0,157 yang menunjukan bahwa arah pengaruh antara kepemimpinan dengan kepuasan kerja adalah positif. Dengan demikian hipotesis H1 dalam penelitian ini yang menyatakan "kepemimpinan berpengaruh positif dan signifikan terhadap kepuasan kerja pegawai BPN NTB" ditolak.

Tabel diatas menunjukan hubungan kompensasi dengan kepuasan kerja adalah berpengaruh signifikan dengan t-statistik sebesar 6,953 (>1,96). Nilai original sample estimate adalah positif yaitu sebesar 0,492 yang menunjukan bahwa arah pengaruh antara kompensasi dengan kepuasan kerja adalah positif. Dengan demikian hipotesis 
H2 dalam penelitian ini yang menyatakan "kompensasi berpengaruh positif dan signifikan terhadap kepuasan kerja pegawai BPN NTB" diterima.

Tabel diatas menunjukan bahwa hubungan pelatihan dan pengembangan dengan kepuasan kerja adalah berpengaruh signifikan dengan t-statistik sebesar 3,601 $(>1,96)$. Nilai original sample estimate adalah positif yaitu sebesar 0,339 yang menunjukan bahwa arah pengaruh antara pelatihan dan pengembangan dengan kepuasan kerja adalah positif. Dengan demikian hipotesis $\mathrm{H} 3$ dalam penelitian ini yang menyatakan "pelatihan dan pengembangan berpengaruh positif dan signifikan terhadap kepuasan kerja pegawai BPN NTB" diterima.

Tabel di atas menunjukan bahwa hubungan antara kepemimpinan dengan produktivitas kerja adalah tidak berpengaruh signifikan dengan t-statistik sebesar 0,817 $(<1,96)$. Nilai original sample estimate adalah positif yaitu sebesar 0,090 yang menunjukan bahwa arah pengaruh antara kepemimpinan dengan produktivitas kerja adalah positif. Dengan demikian hipotesis H4 dalam penelitian ini yang menyatakan "kepemimpinan berpengaruh positif dan signifikan terhadap produktivitas kerja pegawai BPN NTB" ditolak.

Tabel di atas menunjukan bahwa hubungan antara kompensasi dengan produktivitas kerja adalah tidak berpengaruh signifikan dengan t-statistik sebesar 1,426 $(<1,96)$. Nilai original sample estimate adalah negatif yaitu sebesar $-0,162$ yang menunjukan bahwa arah pengaruh antara kompensasi dengan produktivitas kerja adalah negatif. Dengan demikian hipotesis H5 dalam penelitian ini yang menyatakan "kompensasi berpengaruh positif dan signifikan terhadap produktivitas kerja pegawai BPN NTB" ditolak.

Tabel diatas menunjukan bahwa hubungan pelatihan dan pengembangan dengan produktivitas kerja adalah tidak berpengaruh signifikan dengan t-statistik sebesar 1,959 $(<1,96)$. Nilai original sample estimate adalah positif yaitu sebesar 0,271 yang menunjukan bahwa arah pengaruh antara pelatihan dan pengembangan dengan produktivitas kerja adalah positif. Dengan demikian hipotesis H6 dalam penelitian ini yang menyatakan "pelatihan dan pengembangan berpengaruh positif dan signifikan terhadap produktivitas kerja pegawai BPN NTB" ditolak.

Tabel diatas menunjukan bahwa hubungan kepuasan kerja dengan produktivitas kerja adalah berpengaruh signifikan dengan t-statistik sebesar 4,314 $(>1,96)$. Nilai original sample estimate adalah positif yaitu sebesar 0,672 yang menunjukan bahwa arah pengaruh antara kepuasan kerja dengan produktivitas kerja adalah positif. Dengan demikian hipotesis H7 dalam penelitian ini yang menyatakan "kepuasan kerja berpengaruh positif dan signifikan terhadap produktivitas kerja pegawai BPN NTB" diterima.

Berdasarkan nilai original sample estimate diperoleh nilai tertinggi yang mempengaruhi kepuasan kerja adalah kompensasi yaitu sebesar 0,492. Hal tersebut menunjukan bahwa kompensasi mempunyai pengaruh yang paling besar terhadap kepuasan kerja dibandingkan kepemimpinan dan pelatihan pengembangaan. Lebih lanjut variabel yang paling besar pengaruhnya terhadap produktivitas kerja adalah kepuasan kerja dengan nilai original sample estimate tertinggi yaitu sebesar 0,672. Kepuasan kerja mempunyai pengaruh yang paling besar terhadap produktivitas kerja dibandingkan kepemimpinan, kompensasi, dan pelatihan pengembangan. 


\section{Pembahasan}

a. Pengaruh Kepemimpinan terhadap Kepuasan Kerja

Hasil penelitian menunjukan bahwa kepemimpinan tidak berpengaruh terhadap kepuasan kerja pegawai BPN NTB. Ini artinya kepemimpinan yang diukur melalui sembilan indikator yaitu kejelasan pengarahan, rutinitas pengarahan, efektivitas komunikasi, komunikasi menumbuhkan semangat dan loyalitas, pembagian kewenangan dan tanggung jawab, kewenangan yang dibatasi, efektivitas motivasi, profesionalitas pengawasan, dan rutinitas evaluasi, tidak berpengaruh signifikan terhadap kepuasan kerja. Hal ini memberi petunjuk bahwa hipotesis ditolak.

Keefektifan kepemimpinan dalam melaksanakan fungsi-fungsi kepemimpinan dan manajemen di BPN NTB ternyata tidak berpengaruh terhadap kepuasan kerja para pegawainya. Kepemimpinan di BPN NTB baik di tingkat kantor wilayah dan kantor pertanahan tidak dapat menimbulkan kepuasan kerja, dalam hal ini kepuasan kerja terhadap atasan tidak tercapai. Masih banyaknya para atasan yang tidak menjalankan kepemimpinan yang transformasional dan cenderung lebih banyak menjalankan kepemimpinan transaksional dan tidak etis (tidak memberi ketauladanan serta melanggar aturan) membuat para bawahannya kurang simpati, tidak mendukung dan memunculkan perasaan psikologis yang tidak puas dalam bekerja.

b. Pengaruh Kepemimpinan terhadap Produktivitas Kerja

Hasil penelitian menunjukan bahwa kepemimpinan tidak berpengaruh terhadap produktivitas kerja pegawai BPN NTB. Ini artinya kepemimpinan yang diukur melalui sembilan indikator yaitu kejelasan pengarahan, rutinitas pengarahan, efektivitas komunikasi, komunikasi menumbuhkan semangat dan loyalitas, pembagian kewenangan dan tanggung jawab, kewenangan yang dibatasi, efektivitas motivasi, profesionalitas pengawasan, dan rutinitas evaluasi, tidak berpengaruh signifikan terhadap produktivitas kerja. Hal ini memberi petunjuk bahwa hipotesis ditolak.

Menurut Ravianto (1998) faktor-faktor yang mempengaruhi produktivitas kerja pegawai dibagi dalam dua kelompok yakni faktor dari dalam dan dari luar. Para responden merasa bahwa faktor yang lebih berperan mempengaruhi produktivitas kerja pegawai adalah faktor dari dalam dirinya yakni sikap dan etika kerja, gizi dan kesehatan, tingkat pendidikan, tingkat keterampilan, disiplin, motivasi, efesiensi pegawai dalam bekerja, inovasi dan kreatifitas yang lebih berperan mempengaruhi produktivitas kerja responden/ pegawai BPN NTB.

Para responden adalah para eselon IV dalam hal ini mereka adalah para middle manager yang merupakan pegawai terpilih untuk duduk sebagai kasi dan kasubbag di kantor wilayah dan kantor pertanahan kabupaten/ kota di BPN NTB. Kompetensi, kapabilitas, produktivitas kerja dan prestasi kerja telah teruji oleh para Tim Baperjakat (Badan Pertimbangan Jabatan dan Pangkat) BPN NTB sehingga mereka dapat terpilih sebagai pemimpin di setiap seksi dan sub bagian kerja yang ada di BPN NTB. Kepemimpinan dari para Eselon III/ atasan langsung responden bukan merupakan faktor yang berpengaruh terhadap produktivitas kerja responden, dikarenakan mereka merupakan para pegawai yang telah dewasa dan matang sehingga tidak terpengaruh pada gaya kepemimpinan para atasan mereka yang cenderung otoriter, transaksional dan laisse fire. 
c. Pengaruh Kompensasi terhadap Kepuasan Kerja

Hasil penelitian menunjukan bahwa kompensasi berpengaruh terhadap kepuasan kerja pegawai BPN NTB. Ini artinya kompensasi yang diukur melalui sepuluh indikator yakni keadilan kompensasi finansial langsung, keadilan insentif/ penghasilan tambahan, kelayakan kompensasi finansial langsung, ketepatan waktu pemberian kompensasi finansial langsung, keadilan dan kelayakan kompensasi finansial tidak langsung, kemudahan memperoleh cuti-cuti, rutinitas diklat, variasi tugas, peluang promosi terbuka, penghargaan terhadap hasil dan prestasi kerja, serta kenyamanan lingkungan kerja, berpengaruh positif dan signifikan terhadap kepuasan kerja. Hal ini memberikan petunjuk bahwa hipotesis diterima. Indikator ketepatan waktu pemberian kompensasi finansial langsung berpengaruh paling banyak terhadap kompensasi. Hal tersebut mampu mewujudkan rasa keadilan dan kelayakan kompensasi yang diterima pegawai BPN NTB.

Sebagian besar responden menyatakan kompensasi yang diterima telah memenuhi asas keadilan dan kelayakan serta diberikan tepat waktu. Responden mendapatkan kompensasi finansial langsung, kompensasi finansial tidak langsung dan kompensasi non finansial yang kontribusinya sangat dominan meningkatkan kepuasan kerja responden. Bahkan pengaruh kompensasi sangat dominan terhadap kepuasan kerja dibandingkan kepemimpinan dan pelatihan dan pengembangan.

Tujuan pemberian insentif berupa tunjangan kinerja (Tukin) dan uang makan di lingkungan Kementerian Agraria dan Tata Ruang/ BPN serta imbalan jasa berupa honorarium, uang lembur dan lumsum perjalanan dinas telah berdampak positif dan signifikan terhadap kepuasan kerja pegawainya. Semakin besar kompensasi yang didapatkan mampu meningkatkan kepuasan kerja para pegawainya dikarenakan kompensasi yang mereka terima telah memenuhi asas keadilan dan kelayakan.Hanya saja pemberian insentif ini belum diberikan tepat waktu, dimana untuk tunjangan kinerja pencairannya setiap tiga bulan sekali dan honor, uang lembur dan lumsum perjalanan dinas diberikan setelah pegawai melaksanakan tugas kedinasan dan jumlahnya tidak terlalu besar.

d. Pengaruh Kompensasi terhadap Produktivitas Kerja

Hasil penelitian menunjukan kompensasi tidak berpengaruh terhadap produktivitas kerja pegawai BPN NTB. Kompensasi memiliki pengaruh negatif terhadap produktivitas kerja. Ini artinya kompensasi yang diukur melalui sepuluh indikator yakni keadilan kompensasi finansial langsung, keadilan insentif/ penghasilan tambahan, kelayakan kompensasi finansial langsung, ketepatan waktu pemberian kompensasi finansial langsung, keadilan dan kelayakan kompensasi finansial tidak langsung, kemudahan memperoleh cuti-cuti, rutinitas diklat, variasi tugas, peluang promosi terbuka, penghargaan terhadap hasil dan prestasi kerja, serta kenyamanan lingkungan kerja, tidak berpengaruh positif dan signifikan terhadap kepuasan kerja. Hal ini memberikan petunjuk bahwa hipotesis ditolak.

Hasil analisa data berbeda dengan deskripsi variabel jawaban mayoritas responden dimana responden menilai kompensasi yang diterima telah layak dan adil. Indikator ketepatan waktu pemberian kompensasi finansial langsung berpengaruh paling banyak terhadap kompensasi. Hal tersebut mampu mewujudkan rasa keadilan dan kelayakan kompensasi yang diterima pegawai BPN NTB. Faktor kompensasi tidak dominan mempengaruhi produktivitas kerja. Karena yang lebih banyak mempengaruhi produktivitas kerja adalah faktor pelatihan dan 
pengambangan serta kepuasan kerja. Para responden lebih terpacu untuk meningkatkan produktivitas kerja bila diberikan kesempatan untuk mengikuti berbagai diklat-diklat seperti diklat fungsional dan struktural untuk peningkatan kompetensi dan kapabilitas diri.

Penelitian ini menghasilkan kesimpulan bahwa kompensasi memiliki pengaruh yang negatif terhadap produktivitas kerja pegawai BPN NTB. Semakin besar kompensasi yang diterima pegawai semakin menurun produktivitas kerjanya. Hal ini menunjukan bahwa bila kompensasi yang diterima pegawai telah melebihi dari kebutuhan primer dan sekunder membuat pegawai menghabiskan penghasilan untuk kebutuhan-kebutuhan tersier seperti liburan/ rekreasi sehingga kurang fokus/ lengah terhadap penyelesaian pekerjaan. Pegawai BPN NTB yang terbiasa mendapatkan penghasilan tambahan yang tinggi/ "bekerja di tempat yang basah" cenderung bekerja bila ada uangnya saja dan tidak bersikap profesional dalam menyelesaikan pekerjaan-pekerjaannya dikarenakan besarnya kompensasi sudah berada pada tingkatan yang tidak efektif dalam meningkatkan produktivitas dan kinerja pegawai.

e. Pengaruh Pelatihan dan Pengembangan terhadap Kepuasan Kerja

Hasil penelitian menunjukan bahwa pelatihan dan pengembangan berpengaruh signifikan dengan arah pengaruh yang positif terhadap kepuasan kerja pegawai BPN NTB. Ini artinya variabel pelatihan dan pengembangan yang diukur melalui delapan indikator yakni keantusiasan peserta diklat, profesionalitas pelatih diklat, kesesuaian materi diklat dengan kebutuhan pekerjaan, keefektifan metode diklat, penerapan materi diklat dalam pekerjaan, materi diklat yang aplikatif, diklat meningkatkan kompetensi, dan pencapaian tujuan dan sasaran diklat, berpengaruh positif dan signifikan terhadap kepuasan kerja. Hal ini memberikan petunjuk bahwa hipotesis diterima. Tujuan pemberian pelatihan dan pengembangan kepada para pegawai BPN NTB yang berdampak positif dan signifikan terhadap kepuasan kerja tercapai.

Temuan yang menyatakan pelatihan dan pengembangan karyawan berpengaruh juga terhadap kepuasan kerja dihasilkan juga oleh Supatmi, et al. (2013) dimana secara empiris pelatihan berpengaruh positif dan signifikan terhadap kepuasan kerja, semakin tinggi persepsi positif karyawan terhadap pelatihan yang diikuti maka akan semakin tinggi pula kepuasan kerja karyawan tersebut.

Para responden mendapatkan diklat-diklat yang rutin diikuti meliputi diklat struktural maupun non-struktural seperti diklat teknis/ fungsional, diklat struktural dan diklat kepemimpinan untuk meningkatkan kompetensi dan kapabilitas kepemimpinan para responden. Kepuasan terhadap penyelenggaraan diklat terlihat dari sebagian besar responden menyatakan bahwa berbagai diklat yang didapatkan sesuai dengan kebutuhan dan telah mendukung pekerjaan mereka. Penyelenggaraan diklat dari ketepatan sasaran dan tujuan diklat, para pelatih yang profesional, materi, metode dan dampak dari penyelenggaraan diklat sangat baik bagi peningkatan kualitas kerja yang mendorong tercapainya kepuasan kerja pegawai.

Kementerian Agraria dan Tata Ruang/ BPN RI hendaknya bersungguhsungguh dalam memberikan berbagai pelatihan dan pengembangan untuk pegawai baik di tingkat pusat maupun daerah dengan mebudgetkan anggaran yang besar guna membiayai sarana prasarana diklat dan memberi dukungan yang nyata 
kepada para pegawai yang potensial untuk rutin mengikuti berbagai diklat dan melanjutkan jenjang pendidikan formalnya sehingga kedepannya BPN mempunyai sumber daya manusia yang berkualitas, mampu menghadapi perkembangan zaman dan memberikan pelayanan prima kepada masyarakat/ stakeholder.

f. Pengaruh Pelatihan dan Pengembangan terhadap Produktivitas Kerja

Hasil penelitian menunjukan pelatihan dan pengembangan tidak berpengaruh terhadap produktivitas kerja pegawai BPN NTB. Ini artinya variabel pelatihan dan pengembangan yang diukur melalui delapan indikator yakni keantusiasan peserta diklat, profesionalitas pelatih diklat, kesesuaian materi diklat dengan kebutuhan pekerjaan, keefektifan metode diklat, penerapan materi diklat dalam pekerjaan, materi diklat yang aplikatif, diklat meningkatkan kompetensi, dan pencapaian tujuan dan sasaran diklat, tidak berpengaruh signifikan terhadap produktivitas kerja. Hal ini memberikan petunjuk bahwa hipotesis ditolak. Tujuan pemberian pelatihan dan pengembangan kepada para pegawai BPN NTB yang berdampak positif dan signifikan terhadap kepuasan kerja tidak tercapai.

Hasil penelitian yang menemukan bahwa pelatihan tidak berpengaruh secara signifikan terhadap produktivitas didapatkan pula oleh Mapparante (2011). Hal tersebut disebabkan antara lain masih kurangnya frekuensi pelatihan yang pernah diikuti oleh pegawai, pelatihan yang diikuti kurang sesuai dengan keahlian kerja pegawai di kantor, serta tidak semua materi pelatihan terakomodir dengan baik. Selain itu waktu yang digunakan untuk pelatihan biasanya terlalu singkat.

Hasil penelitian ini berbeda dengan hasil deskripsi variabel yang menunjukan pelatihan dan pengembangan berupa diklat-diklat teknis/ fungsional, struktural, kepemimpinan, dll yang didapatkan responden telah mendukung pekerjaan dan membuat tingkat produktivitas kerja mereka semakin baik dengan adanya peningkatan kompetensi dan kapabilitas mereka dalam bekerja. Hal tersebut ditunjukan dengan tercapainya target kerja yang ditetapkan, kualitas dan kuantitas kerja pegawai yang melebihi rata-rata pegawai lainnya, dapat menyelesaikan tugas sebelum batas waktu, melakukan perencanaan sampai evaluasi terhadap pekerjaan, serta melakukan inovasi dan kreativitas dengan tetap berpedoman pada peraturan perundang-undangan yang berlaku.

Pengaruh pelatihan dan pengembangan yang diberikan kepada para responden tidak signifikan dikarenakan tidak semua responden mendapatkan kesempatan untuk rutin mengikuti diklat-diklat. Hanya pegawai tertentu yang sering diikutkan diklat. Diklat yang diberikan tidak tepat sasaran/ para peserta yang dikirim diklat tidak kompeten. Diklat dilaksanakan dalam waktu yang singkat dan dengan perencanaan yang tidak matang, terlihat dari para pelatih yang berasal dari BPN kurang profesional sehingga metode pembelajaran monoton dan tidak dapat diserap seutuhnya. Materi diklat yang disampaikan tidak komprehensif dan tidak disertai dengan praktik-praktik lapangan sehingga penerapan materi diklat yang dapat diaplikasikan langsung dalam menyelesaikan pekerjaan tidak terwujud. Hal-hal diatas yang menyebabkan tujuan diklat untuk meningkatkan produktivitas kerja belum dapat terwujud di BPN NTB.

g. Pengaruh Kepuasan Kerja terhadap Produktivitas Kerja

Hasil penelitian menunjukan kepuasan kerja berpengaruh positif dan signifikan terhadap produktivitas kerja pegawai BPN NTB. Ini artinya variabel kepuasan kerja yang diukur melalui sepuluh indikator yakni kelayakan dan 
ketepatan waktu kompensasi finansial langsung, keadilan kompensasi finansial langsung, ketepatan jabatan dengan spesifikasi pekerjaan, ketepatan penempatan posisi kerja, keamanan, kenyamanan dan kebersihan lingkungan kerja, dukungan dan kerjasama rekan-rekan kerja, rutinitas bimbingan kerja dari atasan, kedekatan dengan atasan, penghargaan dari atasan, tingkat kesenangan dalam bekerja, berpengaruh positif dan signifikan terhadap produktivitas kerja. Hal ini memberi petunjuk bahwa hipotesis diterima. Tujuan peningkatan kepuasan kerja pegawai BPN NTB yang berdampak positif dan signifikan terhadap produktivitas kerja tercapai.

Hanya kepuasan kerja yang berpengaruh signifikan terhadap produktivitas kerja pagawai BPN NTB sedangkan ketiga variabel lainnya yakni kepemimpinan, kompensasi, pelatihan dan pengembangan tidak berpengaruh signifikan terhadap produktivitas kerja pegawai BPN NTB. Hal ini menunjukan bahwa ketiga variabel tidak berpengaruh langsung terhadap produktivitas kerja, melainkan harus ada yang memediasinya seperti variabel kepuasan kerja.

Dari hasil deskripsi variabel menunjukan tingkat kepuasan kerja para responden rata-rata tinggi. Para responden telah mencapai tingkat kepuasan kerja yang meliputi kepuasan terhadap pekerjaan, kepuasan terhadap kompensasi, kepuasan terhadap atasan, kepuasan terhadap rekan sekerja dan kepuasan terhadap lingkungan kerja telah dirasakan tinggi oleh pegawai BPN NTB. Kepuasan kerja yang tinggi akan menimbulkan semangat kerja, meningkatkan komitmen dan loyalitas terhadap organisasi serta produktivitas kerja.

Hal ini sesuai pendapat Sutrisno (2009) bahwa "bila seseorang pekerja atau karyawan merasakan kepuasan dalam bekerja, maka akan menimbulkan semangat dan gairah dalam bekerja dengan demikian akan terjadi peningkatan produktivitas", karena pekerja yang puas adalah pekerja yang produktif. Dari pernyataan diatas terdapat keterkaitan yang sangat kuat antara kepuasan kerja dengan produktivitas kerja karyawan. Karyawan yang memiliki tingkat kepuasan yang baik akan mencurahkan kemampuan, pengetahuan, keterampilan, tenaga dan waktunya untuk perusahaan.

BPN NTB hendaknya selalu menjaga tingkat kepuasan kerja para pegawainya agar selalu berada pada level yang tinggi dengan pelaksanaan tata kelola manajemen yang baik, sehingga kepuasan kerja yang dirasakan tetap efektif meningkatkan produktivitas kerja para pegawai pada level yang tinggi yang pada ujungnya produktivitas kerja organisasi juga tinggi melalui pencapaian berbagai target kerja pertanahan.

\section{Kesimpulan dan Saran}

Dari hasil penelitian dan pembahasan di atas, maka kesimpulan dari penelitian yang dapat diambil adalah :

1. Kepemimpinan berpengaruh positif dan tidak signifikan terhadap kepuasan kerja Pegawai BPN NTB

2. Kompensasi berpengaruh positif dan signifikan terhadap kepuasan kerja Pegawai BPN NTB

3. Pelatihan dan pengembangan berpengaruh positif dan signifikan terhadap kepuasan kerja Pegawai BPN NTB 


\section{Maret 2017}

4. Kepemimpinan berpengaruh positif dan tidak signifikan terhadap produktivitas kerja Pegawai BPN NTB

5. Kompensasi berpengaruh negative dan tidak signifikan terhadap produktivitas kerja Pegawai BPN NTB

6. Pelatihan dan pengembangan berpengaruh positif dan tidak signifikan terhadap produktivitas kerja Pegawai BPN NTB

7. Kepuasan kerja berpengaruh positif dan signifikan terhadap produktivitas kerja Pegawai BPN NTB

8. Kompensasi memiliki pengaruh yang dominan terhadap kepuasan kerja Pegawai BPN NTB

9. Kepuasan kerja memiliki pengaruh yang dominan terhadap produktivitas kerja Pegawai BPN NTB

Adapun saran yang dapat direkomendasikan berdasarkan hasil penelitian ini adalah :

1. Untuk meningkatkan produktivitas kerja Pegawai BPN NTB strategi yang diterapkan oleh BPN NTB telah tepat yakni dengan memperhatikan kepuasan kerja para pegawainya. Kepuasan kerja dapat tercapai apabila kompensasi yang diterima pegawai BPN NTB telah optimal, dalam hal ini pemberian kompensasi (baik kompensasi finansial langsung, kompensasi finansial tidak langsung dan kompensasi non finansial) telah memenuhi asas keadilan, kelayakan, kepatutan dan diberikan tepat waktu. Sehingga dapat memacu semangat, loyalitas dan ketenangan/ kenyamanan pegawai dalam bekerja. Dalam hal pelaksanaan program pelatihan dan pengembangan dengan pemberian diklat-diklat juga telah mendukung pelaksanaan pekerjaan sehingga tercapai kepuasan kerja dan produktivitas kerja yang tinggi.

2. Hendaknya para pemimpin di BPN NTB khususnya para Eselon III di tingkat Kantor Wilayah BPN NTB dan Kantor Pertanahan Kabupaten/ Kota yang ada di NTB lebih melaksanakan fungsi kepemimpinan berupa:

a. Membangun hubungan yang baik dan harmonis kepada para pegawainya

b. Melakukan pembinaan dan pengarahan secara rutin

c. Memberikan wewenang dan tanggungjawab untuk mengambil keputusan

d. Melakukan pengawasan secara profesional terhadap hasil kerja para pegawainya.

3. Untuk meningkatkan kepuasan kerja pegawai terhadap pekerjaan dan lingkungan kerja, BPN NTB dapat melakukan strategi manajemen sumber daya manusia seperti:

a. Memberikan variasi tugas yang menantang sesuai kemampuan dengan melakukan rotasi kerja dan mutasi kerja sehingga para pegawai tidak bosan, selalu terpacu untuk belajar dan mengembangkan diri

b. Melakukan penempatan kerja sesuai kemampuan, keahlian dan pengalaman kerja sehingga pegawai senang bekerja

c. Menciptakan lingkungan kerja aman, nyaman dan bersih dengan sarana dan prasarana kerja yang menunjang.

4. Penelitian ini masih terdapat perbedaan dan kesenjangan dengan penelitian yang lain. Tentu bagi peneliti yang akan datang agar dapat melakukan pengkajian dan penelitian yang lebih mendalam, baik dengan pendekatan penelitian terapan maupun naturalistik terhadap beberapa hasil penelitian ini yang tidak berdampak 


\section{TMM JURNAL MAGISTER MANAJEMEN UNIVERSITAS MATARAM UNRAM \\ Maret 2017}

positif dan signifikan. Seperti pengaruh kepemimpinan terhadap kepuasan kerja pegawai BPN se- Provinsi NTB dan pengaruh kepemimpinan, kompensasi, pelatihan dan pengembangan terhadap produktivitas kerja pegawai BPN seProvinsi NTB.

\section{Daftar Pustaka}

As'ad, Mohamad. (2004). Psikologi Industri, Yogyakarta: Liberty.

Cahyantara, Eka I.P.A., \& Subudi, M. (2015). 'Pengaruh Gaya Kepemimpinan Partisipatif dan Budaya Kerja Terhadap Disiplin Kerja Karyawan dan Produktivitas Kerja Karyawan pada PT PLN Distribusi Bali Selatan'. E-Jurnal Manajemen Unud, Vol. IV (7), 2016-2035.

Celluci, Anthony J dan David L. DeVries. (1978). Measuring Managerial Satisfaction: A Manual for The MJSQ Technical Report II. Centre for Creative Leadership.

David, Fred, R. (2011). Strategic Management Manajemen Strategi Konsep, Edisi 12, Salemba Empat, Jakarta.

Desseler, G. (2015). Manajemen Sumber Daya Manusia Edisi 14, Terjemahan Angelica. Jakarta: Salemba Empat.

Ghozali, I. (2007). Aplikasi Analisis Multivariate dengan Program SPSS. Semarang: Badan Penerbit Universitas Diponegoro.

Ghozali, I. (2015). Partial Least Squares Konsep, Teknik dan Aplikasi Menggunakan Program SmartPLS 3.0 Untuk Penelitian Empiris. Edisi 2. Semarang: Badan Penerbit Universitas Diponegoro.

Handoko, T. Hani. (2001), Manajemen Personalia dan Sumber Daya Manusia (Edisi 2), Yogyakarta : Badan Penerbit Fakultas Ekonomi.

Hasibuan, Melayu. (1996). Organisasi Dan Motivasi, Dasar Peningakatan Produktivitas. Bumi Aksara Putra, Jakarta.

Ingranti, M., Santoso, I., dan Dania, WAP. (2012). 'Pengaruh Komponen Teknologi dan Nilai Tambah Terhadap Perkembangan Sentra Industri Kerupuk Udang Sidoarjo (Studi Kasus di Industri Krupuk Udang Desa Kedungrejo, Keamatan Jabon, Kabupaten Sidoarjo). Jurnal Industry, vol. I (2). 125-139.

Koesmono H, Teman. 2007. Pengaruh Kepemimpinan dan Tuntutan Tugas Terhadap Komitmen Organisasi dengan Variabel Moderasi Motivasi Perawat Rumah Sakit Swasta Surabaya.

Kouzes, J.M. and Posner, B.Z. (2004). Leadership the Challenge. Alih Bahasa oleh Revyani Sjahrial. Jakarta: Erlangga.

Kismono, Gugup. (1999). ‘Perubahan Lingkungan, Transformasi Organisasi dan Reposisi Peran Fungsi Sumberdaya Manusia', Jurnal Ekonomi dan Bisnis Indonesia, vol. XIV (22), 62-76, Magister Manajemen Undip, Semarang.

Kussriyanto, Bambang.(1986). Meningkatkan Produktivitas Karyawan, Penerbit LPPM dan PT. Pusataka Binaan, Jakarta.

Luthans, F. (2006). Perilaku Organisasi. Yogyakarta; Andi.

Mangkunegara, A.P. (2003). Perencanaan dan Pengembangan Sumber Daya Manusia. Bandung: PT Rafika Aditama.

Martoyo, Susilo. (1994), Manajemen Sumber Daya Manusia Edisi 4, Yogyakarta, Penerbit: BPFE.

Mathis, R.L., \& Jackson. J.H. (2009). Human Resource Management Edisi 10. Jakarta: Salemba Empat. 


\section{TMM JURNAL MAGISTER MANAJEMEN UNIVERSITAS MATARAM UNRAM \\ Maret 2017}

Miller, G., R. Beckwith., C. Fellbaum., D. Gross., \& K. Miller. (1990). Word Net: An On-Line Lexical Database. International Journal of Lexicography.

Mondy, R.W. (2008). Manajemen Sumber Daya Manusia. Jakarta: Erlangga.

Ravianto. (1985), Produktivitas dan Manajemen, UGM Press, Yogyakarta.

Rivai, V., \& Sagala, E. J. (2011). Manajemen Sumber Daya Manusia untuk Perusahaan. Jakarta: PT. Raja Grafindo persada.

Robbins, S.P., \& Judge, T.A. (2008). Perilaku Organisasi.Edisi 12. Jakarta: Salemba Empat.

Samsudin, S. (2010). Manajemen Sumber Daya Manusia. Bandung: CV.Pustaka Setia.

Siagian, S. P. (2010), Manajemen Sumber Daya Manusia, Jakarta:PT. Bumi Aksara.

Simamora, H. (2006). Manajemen Sumber Daya Manusia. Edisi III. Yogyakarta: Sekolah Tinggi Ilmu Ekonomi YKPN.

Sinungan, Muchdrasah.(2000), Pruduktivitas, Apa dan Bagaimana, Jakarta: Bumi Aksara.

Stoner, James. A.F., (1991). “Manajemen”, Cetakan ke-3, Erlangga, Jakarta.

Sugiyono. (2014). Metode Penelitian Kuantitatif Kualitatif dan RED. Bandung: Alfabeta.

Supatmi, M.E., Nimran, U., \& Utami, H.N. (2013). Pengaruh Pelatihan, Kompensasi terhadap Kepuasan Kerja dan Kinerja Karyawan, Vol. VII (1), 25-37.

Sutrisno, Edy.(2012), Manajemen Sumber Daya Manusia, Jakarta, Kencana.

Suwatno, \& Priansa, D. J. (2011). Manajemen SDM dalam Organisasi Publik dan Bisnis. Bandung: Alfabeta.

Syafaruddin, A., (2001). Manajemen Sumber Daya Manusia Strategi Keunggulan Kompetitif. BPFE, Yogyakarta.

Yuniarsih, T., \& Suwatno. (2008). Manajemen Sumber Daya Manusia. Bandung: Alfabeta. 